\title{
Using present-day observations to detect when anthropogenic change forces surface ocean carbonate chemistry outside preindustrial bounds
}

\author{
Adrienne J. Sutton ${ }^{1,2}$, Christopher L. Sabine ${ }^{2}$, Richard A. Feely ${ }^{2}$, Wei-Jun Cai ${ }^{3}$, Meghan F. Cronin ${ }^{2}$, \\ Michael J. McPhaden ${ }^{2}$, Julio M. Morell ${ }^{4}$, Jan A. Newton ${ }^{5}$, Jae-Hoon Noh ${ }^{6}$, Sólveig R. Ólafsdóttir ${ }^{7}$, \\ Joseph E. Salisbury ${ }^{8}$, Uwe Send ${ }^{9}$, Douglas C. Vandemark ${ }^{8}$, and Robert A. Weller ${ }^{10}$ \\ ${ }^{1}$ Joint Institute for the Study of the Atmosphere and Ocean, University of Washington, Seattle, WA 98195, USA \\ ${ }^{2}$ Pacific Marine Environmental Laboratory, NOAA, Seattle, WA 98115, USA \\ ${ }^{3}$ School of Marine Science and Policy, University of Delaware, Newark, DE 19716, USA \\ ${ }^{4}$ Department of Marine Sciences, University of Puerto Rico, Mayagüez, 00681, Puerto Rico \\ ${ }^{5}$ Applied Physics Laboratory, University of Washington, Seattle, WA 98105, USA \\ ${ }^{6}$ Korea Institute of Ocean Science and Technology, Ansan Gyunggido 15627, South Korea \\ ${ }^{7}$ Marine Research Institute, Skulagata 4, 101 Reykjavik, Iceland \\ ${ }^{8}$ Ocean Processes Analysis Laboratory, University of New Hampshire, Durham, NH 03825, USA \\ ${ }^{9}$ Scripps Institution of Oceanography, University of California, San Diego, La Jolla, CA 92093, USA \\ ${ }^{10}$ Woods Hole Oceanographic Institution, Woods Hole, MA 02543, USA
}

Correspondence to: Adrienne J. Sutton (adrienne.sutton@noaa.gov)

Received: 18 March 2016 - Published in Biogeosciences Discuss.: 29 March 2016

Revised: 14 July 2016 - Accepted: 26 July 2016 - Published: 13 September 2016

\begin{abstract}
One of the major challenges to assessing the impact of ocean acidification on marine life is detecting and interpreting long-term change in the context of natural variability. This study addresses this need through a global synthesis of monthly $\mathrm{pH}$ and aragonite saturation state $\left(\Omega_{\mathrm{arag}}\right)$ climatologies for 12 open ocean, coastal, and coral reef locations using 3-hourly moored observations of surface seawater partial pressure of $\mathrm{CO}_{2}$ and $\mathrm{pH}$ collected together since as early as 2010. Mooring observations suggest open ocean subtropical and subarctic sites experience present-day surface $\mathrm{pH}$ and $\Omega_{\text {arag }}$ conditions outside the bounds of preindustrial variability throughout most, if not all, of the year. In general, coastal mooring sites experience more natural variability and thus, more overlap with preindustrial conditions; however, present-day $\Omega_{\text {arag }}$ conditions surpass biologically relevant thresholds associated with ocean acidification impacts on Mytilus californianus $\left(\Omega_{\mathrm{arag}}<1.8\right)$ and Crassostrea gigas $\left(\Omega_{\text {arag }}<2.0\right)$ larvae in the California Current Ecosystem (CCE) and Mya arenaria larvae in the Gulf of Maine $\left(\Omega_{\text {arag }}<1.6\right)$. At the most variable mooring loca-
\end{abstract}

tions in coastal systems of the CCE, subseasonal conditions approached $\Omega_{\text {arag }}=1$. Global and regional models and data syntheses of ship-based observations tended to underestimate seasonal variability compared to mooring observations. Efforts such as this to characterize all patterns of $\mathrm{pH}$ and $\Omega_{\text {arag }}$ variability and change at key locations are fundamental to assessing present-day biological impacts of ocean acidification, further improving experimental design to interrogate organism response under real-world conditions, and improving predictive models and vulnerability assessments seeking to quantify the broader impacts of ocean acidification.

\section{Introduction}

The global ocean has absorbed $\sim 30 \%$ of anthropogenic carbon dioxide $\left(\mathrm{CO}_{2}\right)$ emissions released since the beginning of the industrial revolution (Khatiwala et al., 2013; Le Quéré et al., 2015). While ocean uptake of $\mathrm{CO}_{2}$ has played a role in mitigating the atmospheric-associated impacts of anthro- 
pogenic $\mathrm{CO}_{2}$, it has also resulted in changes to seawater chemistry. Seawater $\mathrm{pH}$ has decreased globally by 0.1 since the preindustrial era (Feely et al., 2004; Orr et al., 2005) and is predicted to decrease by another 0.3 by 2100 under Intergovernmental Panel on Climate Change (IPCC) business-asusual emission scenarios (Caldeira and Wickett, 2005; Orr et al., 2005). Ocean acidification also results in reductions in carbonate ion concentrations and the saturation states of calcium carbonate minerals utilized by calcifying marine organisms to make their shells or skeletons. Globally, average surface seawater $\mathrm{pH}$ change is currently about $-0.002 \mathrm{yr}^{-1}$ and the saturation state of aragonite, a common form of calcium carbonate mineral utilized by marine organisms, is approximately $-0.008 \mathrm{yr}^{-1}$ (Bates et al., 2014).

These assessments of ocean-wide change inform globalscale predictions of ocean acidification impacts and provide boundaries on carbonate chemistry in designing biological experiments. However, a major challenge to assessing local- to regional-level ecological and economic consequences of ocean acidification is the lack of understanding of how global anthropogenic change manifests relative to natural variability, especially in dynamic coastal regions (Bauer et al., 2013). Coastal systems are sites of large variability, where terrestrial, atmospheric, and marine nutrient and carbon cycles all interact and where ocean acidification conditions can be more extreme than in open ocean environments (Cai et al., 2011; Feely et al, 2010). Important processes that affect ocean acidification in the coastal ocean include upwelling, riverine/estuarine input, air-sea gas exchange, production and respiration, calcification, dissolution, sediment burial, and sea-ice dynamics. Despite the ecological, biological, and economic importance of coastal regions, the magnitude and variability of these key biogeochemical processes are poorly quantified.

Earth system models provide some insights into carbon system variability; however, they do not often capture the full magnitude of variability, especially at seasonal to subseasonal timescales (Pilcher et al., 2015; Sasse et al., 2015). For example, Sasse et al. (2015) estimated that earth system models underpredict the seasonal cycle of seawater partial pressure of $\mathrm{CO}_{2}$, i.e., $p\left(\mathrm{CO}_{2}\right)$, by $30 \%$. Despite these biases, some studies have made progress by utilizing current estimates of $\Omega_{\text {arag }}$ variability and change in assessing ecosystem impact and vulnerability to ocean acidification. Using predicted aragonite saturation state $\left(\Omega_{\text {arag }}\right)$ change between 2005 and 2050 and an estimate of annual variability from the Community Climate System Model (CCSM) 3.1, Cooley et al. (2009) identified that ocean acidification will exceed natural conditions throughout the global ocean by 2050 , especially in low-latitude regions of the Atlantic, Indian, and western Pacific. Applying similar approaches to three other earth system models, Friedrich et al. (2012) also concluded that these regions are most vulnerable, but also found that present-day ocean acidification already exceeds preindustrial variability by a factor of 5 in shallow water tropical Pacific and Atlantic coral reef ecosystems. Both studies pointed out that these global models do not currently resolve coastal processes and therefore lack important sources of natural variability, which bias these results when extrapolating to coastal and coral systems. In a vulnerability assessment of US shellfisheries, this lack of coastal information was addressed by using earth system model output as a baseline for $\Omega_{\text {arag }}$ conditions but also by adding a term in the final assessment for amplification of ocean acidification in coastal systems that experience eutrophication, upwelling, and river inputs of low $\Omega_{\text {arag }}$ water (Ekstrom et al., 2015). Although this approach did not resolve all coastal carbonate variability and change, it allowed for some of the first regional-level assessments of ocean acidification impact. Regional models in coastal systems are also showing promise at eddy-resolving spatial scales and monthly to seasonal temporal scales. Applied to the California Current Ecosystem (CCE), regional models predict that surface ocean $\Omega_{\text {arag }}$ has already moved outside the bounds of preindustrial variability (Hauri et al., 2013). Direct measurements of the full range of variability will help parameterize and evaluate these models.

Defining present-day seawater carbonate conditions can also contribute to studies addressing how marine life responds to a myriad of stressors. Biological impacts could manifest, for example, through exposure to conditions beyond the baseline, preindustrial conditions to which marine life is adapted. In a field experiment within a natural coral reef system, Albright et al. (2016) found that net community calcification increased when seawater chemistry was modified to preindustrial conditions. Preindustrial conditions likely varied among different ecosystems, so designing biological impact studies like this depends on defining the natural range of variability and identifying when and where other organisms may be exposed to conditions outside of this range. Biological impacts may also manifest once seawater carbonate conditions surpass a certain physiological threshold. Many experiments have focused on measuring biological response to undersaturated $\Omega_{\text {arag }}$ conditions; however, recent studies have identified physiological thresholds for shellfish larvae at $\Omega_{\text {arag }}>1$ (Barton et al., 2012; Gaylord et al., 2011; Hettinger et al., 2013; Salisbury et al., 2008; Waldbusser et al., 2015a, b). Knowledge about when and where these corrosive conditions occur and how the timing of such conditions relate to key life stages is critical to assessing vulnerability to ocean acidification.

Understanding what dominant patterns of variability define the natural range of carbonate chemistry is also critical to future predictions of impact. Whether the variability is dominated by stochastic events (e.g., storms), the seasonal cycle, interannual variability (e.g., El Niño and La Niña events), or decadal climactic oscillations (e.g., Pacific Decadal Oscillation) will control how climate change impacts these natural variations in ocean carbonate chemistry. By resolving these scales of variability, researchers can start to refine biological experiments, ecosystem models, and economic vulnera- 
bility assessments in the context of full ecosystem variability and change. As evidence emerges that some shelled marine organisms are already being impacted by corrosive seawater chemistry conditions (Barton et al., 2012; Bednaršek et al., 2012, 2014a, b; Reum et al., 2015) and stakeholders are seeking locally relevant solutions (Kelly and Caldwell, 2013; Kelly et al., 2011), these analyses are becoming increasingly important.

High-frequency moored observations can be highly effective in capturing the full range of variability at key locations (Cullison Gray et al., 2011; Harris et al., 2013; Hofmann et al., 2011; Shadwick et al., 2015; Sutton et al., 2014a; Xue et al., 2016). Here we present the first global-scale ocean acidification mooring synthesis of 3-hourly surface ocean $\mathrm{pH}$ observations and $\Omega_{\text {arag }}$ calculated from direct measurements of $p\left(\mathrm{CO}_{2}\right)$ and $\mathrm{pH}$ collected together on 12 open ocean, coastal, and coral reef moorings since as early as 2010. We used these observations to define present-day and preindustrial subseasonal to interannual $\mathrm{pH}$ and $\Omega_{\text {arag variability at each location, }}$ and compared these observations to past modeling estimates of seasonal to interannual variability of $\Omega_{\text {arag. This assess- }}$ ment identifies the patterns in which present-day conditions have exceeded preindustrial bounds and biologically relevant thresholds at these mooring locations, and documents when and where marine life currently encounters ocean acidification conditions that may impact growth and survival.

\section{Methods}

In 2003, the National Oceanographic and Atmospheric Administration's (NOAA) Pacific Marine Environmental Laboratory (PMEL) began to establish a global moored $\mathrm{CO}_{2}$ network that presently includes 38 mooring locations (www. pmel.noaa.gov/co2/). With the recent development of autonomous $\mathrm{pH}$ sensors, PMEL has been able to expand this network to include $\mathrm{pH}$ at 21 of the mooring locations. These moored $\mathrm{CO}_{2}$ and ocean acidification time series are part of a long-term, sustained effort intended to advance our scientific understanding of the ocean carbon cycle and how it is changing over time. This network leverages other observing system efforts including, but not limited to, the National Data Buoy Center, the Research Moored Array for AfricanAsian-Australian Monsoon Analysis and Prediction, and the OceanSITES network. This study focuses on 12 of these moorings with paired $p\left(\mathrm{CO}_{2}\right)$ and $\mathrm{pH}$ measurements that allow for estimates of subseasonal to interannual variability of $\mathrm{pH}$ and $\Omega_{\mathrm{arag}}$ (Fig. 1, Table 1). This set of moorings includes sites in each major ocean basin and in a variety of open ocean, coastal, and coral reef environments. The time series used in this study include observations primarily between 2010 and 2015, with the exception of the WHOTS time series, which goes back to 2004. "Present-day" observations used here refer to these time series outlined in Table 1.
Each mooring time series summarized in Table 1 included a Moored Autonomous $p\left(\mathrm{CO}_{2}\right)\left(\mathrm{MAPCO}_{2}\right)$ system and a Sunburst SAMI-pH sensor deployed on the surface buoy. For a detailed description of the $\mathrm{MAPCO}_{2}$ system and data processing, refer to Sutton et al. (2014b). In brief, the $\mathrm{MAPCO}_{2}$ system utilizes an automated equilibrator-based gas collection system to measure surface seawater $x\left(\mathrm{CO}_{2}\right)$ (the mole fraction of $\mathrm{CO}_{2}$ in air in equilibrium with surface seawater) every $3 \mathrm{~h}$ in addition to sample temperature, pressure, and relative humidity. The $x\left(\mathrm{CO}_{2}\right)$ measurement is made by a nondispersive infrared gas analyzer (LI-820, LI-COR) calibrated before, during, and after field deployment with reference gases traceable to World Meteorological Organization standards. A Sea-Bird Electronics (SBE) 16plus V2 SeaCAT was also deployed and integrated with the $\mathrm{MAPCO}_{2}$ system to collect sea surface temperature (SST) and salinity (SSS) measurements used to calculate $p\left(\mathrm{CO}_{2}\right)$ consistent with ocean $\mathrm{CO}_{2}$ standard operating procedures (Dickson, 2007; Weiss, 1974). Overall uncertainty of the $\mathrm{MAPCO}_{2}$ is $<2 \mu$ atm for seawater $p\left(\mathrm{CO}_{2}\right)$. The SAMI-pH sensor utilizes the spectrophotometric method for measuring seawater $\mathrm{pH}$ with a laboratory-based accuracy of \pm 0.003 and precision of $<0.001$ (Seidel et al., 2008).

The SAMI-pH and SBE SeaCAT sensors collected 3hourly measurements during the $\mathrm{MAPCO}_{2} 10 \mathrm{~min}$ seawater equilibration time. All sensors were factory calibrated between each 1 year deployment. Data quality control for the SAMI-pH data involved utilizing the sensor software to identify and flag outliers and sensor failures such as bad blanks. We also used the relationship between total alkalinity $\left(A_{\mathrm{T}}\right)$ and SSS (Cullison Gray et al., 2011; Fassbender, 2014; Lee et al., 2006; Xue et al., 2016) to calculate $\mathrm{pH}$ from $p\left(\mathrm{CO}_{2}\right)$ and $A_{\mathrm{T}}$ (using the CO2SYS program) in order to identify sensor drift within a deployment or offsets between deployments, which only occurred in $8 \%$ of the $\mathrm{pH}$ data sets. All $\mathrm{pH}$ data are on the total $\mathrm{pH}$ scale (Dickson et al., 2007). Data quality control for the SBE SeaCAT was limited to flagging and eliminating outliers. All measurements are archived at the relevant data centers: the Carbon Dioxide Information Analysis Center (http://cdiac.ornl. gov/oceans/Moorings/) and the National Centers for Environmental Information (https://www.ncei.noaa.gov/).

In all calculations of $\Omega_{\text {arag }}$ we used the MATLAB version (v1.1) of the CO2SYS program (Lewis and Wallace, 1998; van Heuven et al., 2011) with the carbonic acid dissociation constants of Lueker et al. (2000), sulfate dissociation constants of Dickson (1990), and borate-to-salinity ratio of Lee et al. (2010) according to recommended best practices (Dickson, 2007; Orr et al., 2015). We also used average surface ocean phosphate and silicate concentrations from the World Ocean Atlas 2009 for each mooring location (Garcia et al., 2010). We used two pairs of carbonate system parameters to calculate $\Omega_{\text {arag }}$ : (1) $p\left(\mathrm{CO}_{2}\right)$ and $\mathrm{pH}$ observations and (2) $p\left(\mathrm{CO}_{2}\right)$ observations and $A_{\mathrm{T}}$ estimated from SSS (Cullison Gray et al., 2011 for CCE2 and Chá bă; Fassbender, 2014 
Table 1. Details on each surface seawater $p\left(\mathrm{CO}_{2}\right)$ and $\mathrm{pH}$ mooring time series including abbreviation, name, coordinates, and dates of time series. $n$ is the total number of 3-hourly samples for each $\mathrm{pH}$ and $\Omega_{\mathrm{arag}}$ time series. Finalized data sets can be found organized by mooring location by navigating through the clickable $\mathrm{CO}_{2}$ data portal map at http://cdiac.ornl.gov/oceans/Moorings/.

\begin{tabular}{|c|c|c|c|c|c|}
\hline Abbreviation & Full name & Latitude & Longitude & Dates of time series & $n$ \\
\hline WHOTS & $\begin{array}{l}\text { WHOI Hawaii Ocean Time- } \\
\text { series station }\end{array}$ & 22.7 & -158.0 & Dec 2004-Mar 2014 ${ }^{\mathrm{a}}$ & 18532 \\
\hline Stratus & Stratus & -19.7 & -85.6 & May 2012-Jul 2013 & 3193 \\
\hline ВОВОА & $\begin{array}{l}\text { Bay of Bengal Ocean Acidifica- } \\
\text { tion Mooring } b\end{array}$ & 15.0 & 90.0 & Nov 2013-Aug 2015 & 4085 \\
\hline Iceland & $\begin{array}{l}\text { North Atlantic Ocean Acidifi- } \\
\text { cation Mooring }\end{array}$ & 68.0 & -12.6 & Aug 2013-Jul 2015 & 2671 \\
\hline Papa & Ocean Station Papa & 50.1 & -144.8 & Jun 2010-Dec 2013 & 6005 \\
\hline KEO & $\begin{array}{l}\text { Kuroshio Extension Observa- } \\
\text { tory }\end{array}$ & 32.3 & 144.6 & Nov 2011-Jun 2015 & 5540 \\
\hline Chá bă & $\begin{array}{l}\text { Chá bă Mooring within the } \\
\text { Northwest Enhanced Moored } \\
\text { Observatory }\end{array}$ & 48.0 & -125.0 & Jul 2010-Apr 2014 & 5115 \\
\hline CCE2 & California Current Ecosystem 2 & 34.3 & -120.8 & Mar 2012-Mar 2015 & 3197 \\
\hline Gray's Reef & $\begin{array}{l}\text { National Data Buoy Center } \\
\text { buoy at Gray's Reef National } \\
\text { Marine Sanctuary }\end{array}$ & 31.4 & -80.9 & Nov 2010-Sep 2015 & 4184 \\
\hline Gulf of Maine & $\begin{array}{l}\text { Coastal Western Gulf of Maine } \\
\text { Mooring }\end{array}$ & 43.0 & -70.5 & Sep 2010-Jul 2013 & 5392 \\
\hline Chuuk & Chuuk Lagoon Mooring & 7.5 & 151.9 & Dec 2011-Sep 2014 & 2274 \\
\hline La Parguera & $\begin{array}{l}\text { La Parguera Ocean Acidifica- } \\
\text { tion Mooring }\end{array}$ & 18.0 & -67.1 & Dec 2012-Oct 2014 & 2833 \\
\hline
\end{tabular}

Notes: ${ }^{a}$ the WHOTS time series includes mooring $p\left(\mathrm{CO}_{2}\right)$ observations from the Multi-disciplinary Ocean Sensors for Environmental Analyses and Networks station at $22.8^{\circ} \mathrm{N}, 158.1^{\circ} \mathrm{W}$ from 2004 to 2007. ${ }^{\mathrm{b}}$ The BOBOA mooring is embedded within the Research Moored Array for African-Asian-Australian Monsoon Analysis and Prediction (RAMA; McPhaden et al., 2009).

for Papa and KEO; C. Hunt, University of New Hampshire, personal communication, 2016 for Gulf of Maine; Xue et al., 2016 for Gray's Reef; and Lee et al., 2006 for the remaining sites). We then averaged the two $\Omega_{\text {arag }}$ data sets for the final present-day $\Omega_{\text {arag }}$ values presented here. The only exception to the $\Omega_{\text {arag }}$ calculations was the WHOTS mooring time series where we have good $\mathrm{pH}$ data over multiple years but only during the months of June to November. For this site we used only $p\left(\mathrm{CO}_{2}\right)$ and $A_{\mathrm{T}}$ estimated according to Lee et al. (2006)

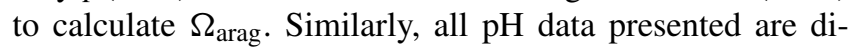
rect autonomous measurements of $\mathrm{pH}$ except in the case of the WHOTS mooring where $\mathrm{pH}$ was calculated from $p\left(\mathrm{CO}_{2}\right)$ observations and estimated $A_{\mathrm{T}}$ using CO2SYS.

We used this approach of averaging calculated $\Omega_{\text {arag }}$ from $p\left(\mathrm{CO}_{2}\right)$ and $\mathrm{pH}$ observations $\left(\Omega_{\text {arag: }} p \mathrm{CO}_{2}-\mathrm{pH}\right)$ and calculated $\Omega_{\text {arag }}$ from $p\left(\mathrm{CO}_{2}\right)$ observations and estimated $A_{\mathrm{T}}$ ( $\Omega_{\text {arag: }} p \mathrm{CO}_{2}$-AT) to minimize the following errors: (1) the covariance of $p\left(\mathrm{CO}_{2}\right)$ and $\mathrm{pH}$ can lead to small errors in predicting $\Omega_{\text {arag }}$, which can enhance $\Omega_{\text {arag }}$ variability (Cullison Gray et al., 2011; Millero, 2007), and (2) the $A_{\mathrm{T}}$ proxies only account for dilution and evaporation processes, which can result in underestimation of $A_{\mathrm{T}}$ variability and, when combined with other carbon parameters, can reduce surface

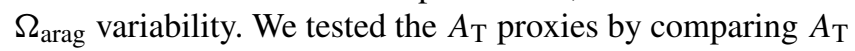

measured from discrete bottle samples collected at the surface at each mooring site to $A_{\mathrm{T}}$ estimated from the proxies listed above, which were developed using $A_{\mathrm{T}}$ and SSS measurements throughout the mixed layer. $A_{\mathrm{T}}$ estimated from 3-hourly moored SSS was generally within stated errors (3 to $20 \mu \mathrm{mol} \mathrm{kg}{ }^{-1}$ ) of discrete $A_{\mathrm{T}}$ (e.g., Table 2). However, at a few sites where discrete $A_{\mathrm{T}}$ was measured at the highest frequency (weekly to seasonally; sample size $[n]>100$ ), discrete $A_{\mathrm{T}}$ was more variable than $A_{\mathrm{T}}$ estimated from the $A_{\mathrm{T}^{-}}$ SSS proxies (Table 2). At the La Parguera (coral reef) and WHOTS (open ocean) mooring sites, variability of discrete $A_{\mathrm{T}}$ (as measured by 1 standard deviation (SD) of the mean) was greater than estimated $A_{\mathrm{T}}$ by 21 and $52 \%$, respectively.

In addition to the discrepancies in discrete and proxy $A_{\mathrm{T}}$ data sets, the SD of both $\Omega_{\text {arag }}$ calculated from discrete measurements ( $\Omega_{\text {arag: discrete }}$ ) and $\Omega_{\text {arag: }} p \mathrm{CO}_{2}-\mathrm{pH}$ were greater than $\Omega_{\text {arag }}$ calculated from the $p\left(\mathrm{CO}_{2}\right)-A_{\mathrm{T}}$ and $\mathrm{pH}-$ $A_{\mathrm{T}}$ pairs ( $\Omega_{\text {arag: }} p \mathrm{CO}_{2}$-AT and $\Omega_{\text {arag: } \mathrm{pH}-\mathrm{AT}}$; Table 2 ). One limitation of the WHOTS data set is that high-frequency, moored $\mathrm{pH}$ observations only exist during the months of June to November; thus, the mean and SD of the $\Omega_{\text {arag: }} p \mathrm{CO}_{2}-\mathrm{pH}$ and $\Omega_{\text {arag: } \mathrm{pH}-\mathrm{AT}}$ data sets may be biased. Therefore, we used La Parguera as a guide and assumed that actual variability (i.e., from high-quality discrete bot- 


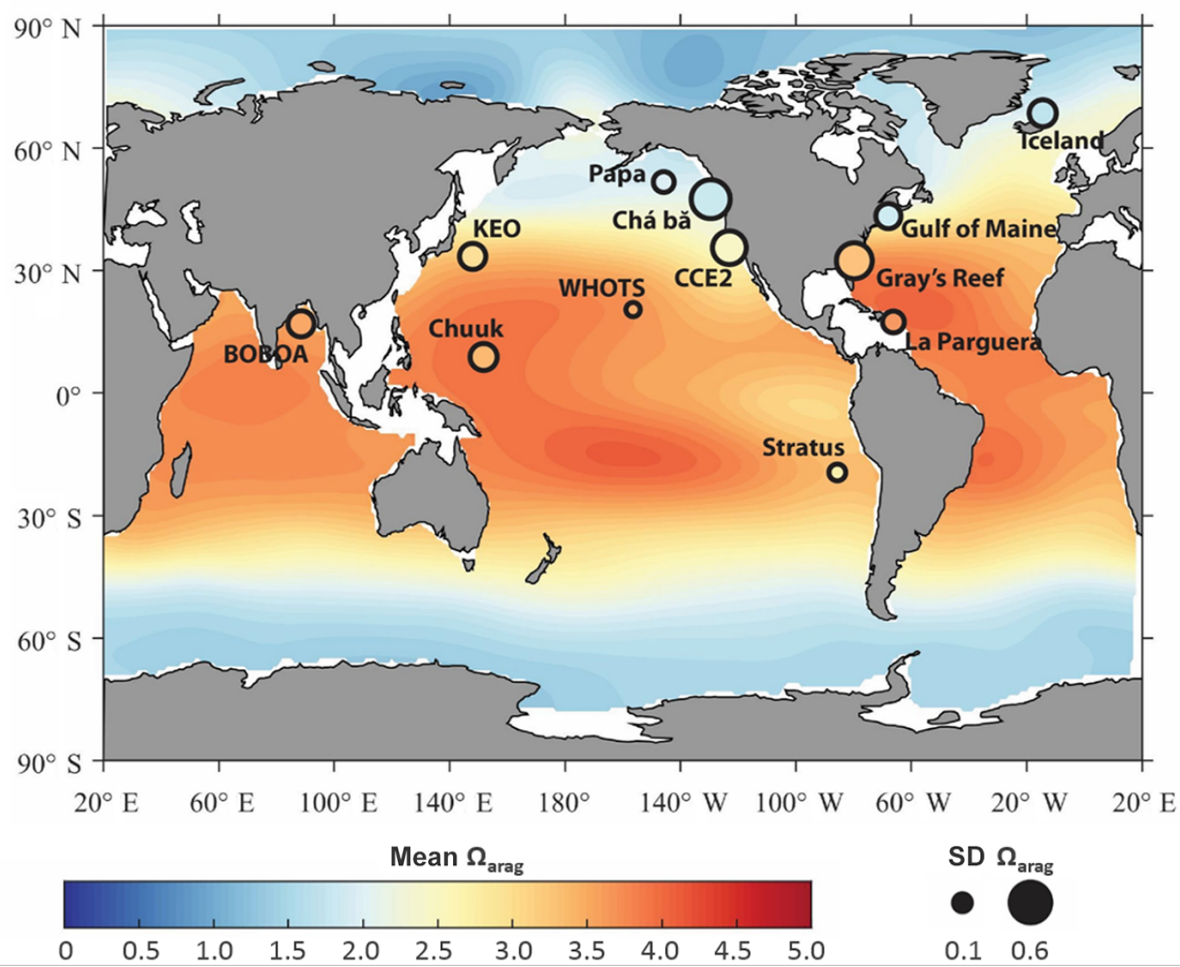

Figure 1. Locations of moored $p\left(\mathrm{CO}_{2}\right)$ and $\mathrm{pH}$ observations. Base map is adapted from Jiang et al. (2015) and shows annual climatological distribution of surface $\Omega_{\text {arag }}$ throughout the global oceans. Added to this base map are moorings from this study where symbol color denotes

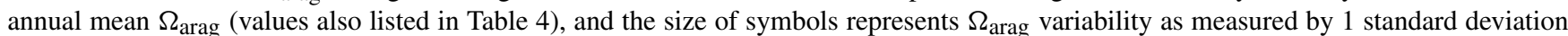
(SD) of the annual mean.

tle samples) of $\Omega_{\text {arag }}\left(\Omega_{\text {arag: discrete }} \mathrm{SD}=0.16\right)$ lies between $\Omega_{\text {arag: } p \mathrm{CO}_{2}-\mathrm{pH}}(\mathrm{SD}=0.19)$ and $\Omega_{\text {arag }}$ calculated from estimated $A_{\mathrm{T}}\left(\Omega_{\text {arag: }} p \mathrm{CO}_{2}\right.$-AT $\mathrm{SD}=0.12 ; \Omega_{\text {arag: } \mathrm{pH}-\mathrm{AT}} \mathrm{SD}$ of 0.13 ; Table 2); we used the approach of averaging mooring ocean acidification data sets to reflect this. Since we are confident in the uncertainty of the moored autonomous $p\left(\mathrm{CO}_{2}\right)$ measurements (Sutton et al., 2014b), for $\Omega_{\text {arag }}$ calculated from estimated $A_{\mathrm{T}}$ we selected $\Omega_{\text {arag: }} p \mathrm{CO}_{2}$-AT to average with $\Omega_{\text {arag: }} p \mathrm{CO}_{2}$-pH. While there were not enough discrete measurements to do this same comparison at the coastal sites, we found that the $\Omega_{\text {arag: }} p \mathrm{CO}_{2}-\mathrm{pH}, \Omega_{\text {arag: }} p \mathrm{CO}_{2}-\mathrm{AT}$, and $\Omega_{\text {arag: }}$ pH-AT data sets were not significantly different $(p<0.05)$ at the coastal sites, likely due to high natural variability in the coastal carbon system. This suggests that averaging $\Omega_{\text {arag: }} p \mathrm{CO}_{2}$-pH and $\Omega_{\text {arag: }} p \mathrm{CO}_{2}$-AT vs. using one $\Omega_{\text {arag }}$ data set will not have a significant impact on results.

The ideal method for calculating $\Omega_{\text {arag }}$ may differ across sites dependent on access to and analysis of high-quality ship-based measurements. However, averaging $\Omega_{\text {arag: }} p \mathrm{CO}_{2}$-pH and $\Omega_{\text {arag: }} p \mathrm{CO}_{2}$-AT provides a conservative estimate of monthly $\Omega_{\text {arag }}$ conditions allowing for a broad-scale comparison with consistent methodology across 12 buoys in different marine ecosystems. Continued high-frequency (ideally, weekly to monthly where feasible) discrete sampling, development and analysis of regional $A_{\mathrm{T}}$ proxies, and devel- opment of autonomous sensors capable of measuring carbonate parameters other than $p\left(\mathrm{CO}_{2}\right)$ and $\mathrm{pH}$ will all help to further refine these methods for calculating $\Omega_{\text {arag }}$ from moored autonomous observations.

To estimate preindustrial $\mathrm{pH}$ and $\Omega_{\mathrm{arag}}$, we used $p\left(\mathrm{CO}_{2}\right)$ and $A_{\mathrm{T}}$ with the following adjustments to present-day observed $p\left(\mathrm{CO}_{2}\right)$ and SST: (1) a decrease of $105 \mathrm{ppm}$ in surface ocean $p\left(\mathrm{CO}_{2}\right)$ assuming the delta between atmospheric and surface seawater $p\left(\mathrm{CO}_{2}\right)$ has remained constant from the preindustrial era to a reference year of 2010 (from Pieter Tans, NOAA/ESRL, www.esrl.noaa.gov/gmd/ccgg/trends/), and (2) changes in SST that vary regionally from 0.5 to $1.5^{\circ} \mathrm{C}$ consistent with the IPCC Fifth Assessment Report (Rhein et al., 2013). Although magnitudes of atmospheric $\mathrm{CO}_{2}$ uptake can also vary regionally (Bauer et al., 2013), for the purposes of this synthesis we assumed that the change in air-sea $\mathrm{CO}_{2}$ differences was consistent globally but that SST changes varied regionally as presented by Rhein et al. (2013). We also assumed small changes in SSS, $A_{\mathrm{T}}$, phosphate, or silicate since the preindustrial era would not have a significant impact on calculated $\mathrm{pH}$ and $\Omega_{\mathrm{arag}}$. We applied these changes to monthly mean and range of variability of presentday observations, and used CO2SYS to calculate preindustrial $\mathrm{pH}$ and $\Omega_{\mathrm{arag}}$. The range of monthly variability in preindustrial and present-day conditions was defined by descrip- 
Table 2. Mean and variability, as measured by $1 \mathrm{SD}$, for $A_{\mathrm{T}}$ and

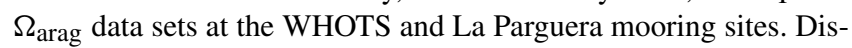
crete measurements for WHOTS are from the Hawaii Ocean Timeseries program (http://hahana.soest.hawaii.edu/hot/) and for La Parguera are from the Atlantic Ocean Acidification Test-Bed project. Proxy $A_{\mathrm{T}}$ measurements are estimated from moored SST and SSS using Lee et al. (2006) $A_{\mathrm{T}}-\mathrm{SSS}$ relationships. $p\left(\mathrm{CO}_{2}\right)$ and $\mathrm{pH}$ used to calculate $\Omega_{\text {arag }}$ are direct observations from the mooring time series; $A_{\mathrm{T}}$ used to calculate $\Omega_{\text {arag }}$ are the $A_{\mathrm{T}}$ proxy measurements.

\begin{tabular}{llrr}
\hline & & WHOTS & La Parguera \\
\hline \multirow{2}{*}{ Mean } & discrete $A_{\mathrm{T}}$ & 2307 & 2290 \\
& proxy $A_{\mathrm{T}}$ & 2310 & 2298 \\
SD & discrete $A_{\mathrm{T}}$ & 16 & 44 \\
& proxy $A_{\mathrm{T}}$ & 9 & 39 \\
& $\Omega_{\text {arag: discrete }}$ & 3.68 & 3.60 \\
& $\Omega_{\text {arag: } p \mathrm{CO}_{2} \text {-AT }}$ & 3.58 & 3.65 \\
& $\Omega_{\text {arag: } \mathrm{pH}-\mathrm{AT}}$ & $3.56^{*}$ & 3.59 \\
& $\Omega_{\text {arag: }} \mathrm{CO}_{2}$-pH & $3.60^{*}$ & 3.50 \\
& $\Omega_{\text {arag: } \text { discrete }}$ & 0.11 & 0.16 \\
& $\Omega_{\text {arag: } p \mathrm{CO}_{2} \text {-AT }}$ & 0.07 & 0.12 \\
& $\Omega_{\text {arag: } \mathrm{pH}-\mathrm{AT}}$ & $0.05^{*}$ & 0.13 \\
& $\Omega_{\text {arag: }} p \mathrm{CO}_{2}$ - $\mathrm{pH}$ & $0.08^{*}$ & 0.19 \\
\hline
\end{tabular}

Notes: ${ }^{*}$ while other observations listed here span the full annual cycle, the WHOTS mooring $\mathrm{pH}$ observations only cover the months of June to November.

tive statistics used in box and whisker plots excluding outliers:

lower limit $=\mathrm{Q} 1-1.5 \times \mathrm{IQR}$

upper limit $=\mathrm{Q} 3+1.5 \times \mathrm{IQR}$,

where Q1 is the 25th percentile (or first quartile), Q3 is the 75th percentile (or third quartile), and IQR is the interquartile range (Q3-Q1) of $\mathrm{pH}$ and $\Omega_{\text {arag }}$ values. These limits equate to approximately $\pm 2.7 \mathrm{SD}$ of the mean for a normally distributed data set.

The variables used to estimate total uncertainty of presentday calculated $\Omega_{\text {arag }}$ are shown in Table 3 . This uncertainty estimate included a preliminary assessment of in situ validation similar to $p\left(\mathrm{CO}_{2}\right)$ validation by Sutton et al. (2014b) to estimate $\mathrm{pH}$ error in the field. The average difference between SAMI-pH measurements and $\mathrm{pH}$ calculated from discrete measurements of dissolved inorganic carbon and $A_{\mathrm{T}}$ was \pm 0.018 , which was larger than laboratory-based assessments of $\mathrm{pH}$ measurement error (Seidel et al., 2008). While this estimate included error caused by slight mismatches in space $(<1 \mathrm{~km})$ and time $(<1.5 \mathrm{~h})$ between the moored and discrete measurements, we used it here to develop a conservative estimate of total estimated uncertainty for calculated $\Omega_{\text {arag: }} p \mathrm{CO}_{2}-\mathrm{pH}$ from moored observations, which is 0.37 for seawater at SST of $25^{\circ} \mathrm{C}$, SSS of $35, p\left(\mathrm{CO}_{2}\right)$ of $370 \mu \mathrm{atm}$, and a $\mathrm{pH}$ of 8.1 (Table 3 ). This estimate meets the target relative uncertainty for $\Omega_{\text {arag }}$ of $10 \%$ needed to identify relative spatial patterns and short-term variation in ocean acidifica-
Table 3. Sources of error to the calculation of $\Omega_{\text {arag }}$ at SST of $25^{\circ} \mathrm{C}$, SSS of $35, p\left(\mathrm{CO}_{2}\right)$ of $370 \mu \mathrm{atm}$, a $\mathrm{pH}$ of $8.1, A_{\mathrm{T}}=2350$, and $\Omega_{\mathrm{arag}}$ of 3.7. Total estimated absolute (relative) uncertainty was calculated using the root sum of squares (RSS) method: $\operatorname{RSS}=\left(\sum e^{2}\right)^{1 / 2}$.

\begin{tabular}{|c|c|c|}
\hline Sources of error & Variable error $( \pm)$ & $\begin{array}{r}\text { Effect on } \\
\text { error of } \Omega_{\text {arag }} \\
\text { calculation }(e)\end{array}$ \\
\hline \multicolumn{3}{|l|}{$p \mathrm{CO}_{2}$ and $\mathrm{pH}$ pair: } \\
\hline$p \mathrm{CO}_{2}$ measurement & $2 \mu a m^{a}$ & 0.02 \\
\hline $\mathrm{pH}$ measurement & 0.018 & 0.32 \\
\hline$K_{0}$ & $0.004^{b}$ & \\
\hline$K_{1}$ & $0.015^{b}$ & \\
\hline \multirow[t]{2}{*}{$K_{2}$} & $0.03^{\mathrm{b}}$ & $0.18^{\mathrm{c}}$ \\
\hline & $\begin{array}{l}\text { Estimated uncertainty } \\
\text { of } \Omega_{\text {arag: }} p \mathrm{CO}_{2}-\mathrm{pH}\end{array}$ & $0.37(10 \%)$ \\
\hline \multicolumn{3}{|l|}{$p \mathrm{CO}_{2}$ and $A_{\mathrm{T}}$ pair: } \\
\hline$p \mathrm{CO}_{2}$ measurement & $2 \mu \mathrm{atm}^{\mathrm{a}}$ & 0.02 \\
\hline$A_{\mathrm{T}}$ proxy & $3-20 \mu \mathrm{mol} \mathrm{kg}-1 \mathrm{~d}$ & $0.01-0.05$ \\
\hline$K_{0}$ & $0.004^{b}$ & \\
\hline$K_{1}$ & $0.015^{b}$ & \\
\hline \multirow[t]{2}{*}{$K_{2}$} & $0.03^{\mathrm{b}}$ & $0.18^{\mathrm{c}}$ \\
\hline & $\begin{array}{l}\text { Estimated uncertainty } \\
\quad \text { of } \Omega_{\text {arag: }} p \mathrm{CO}_{2}-\mathrm{AT}\end{array}$ & $0.19(5 \%)$ \\
\hline
\end{tabular}

Notes: ${ }^{\mathrm{a}}$ from Sutton et al. (2014b). ${ }^{\mathrm{b}}$ Error estimates of thermodynamic constants from McLaughlin et al. (2015). ${ }^{c}$ Combined effect of thermodynamic constants (Mucci et al., 1983). ${ }^{\mathrm{d}}$ Range of error from AT proxies described in methods.

tion (Newton et al., 2015). A more detailed assessment of $\mathrm{pH}$ sensor error is planned as more discrete and autonomous $\mathrm{pH}$ data become available. When the $\mathrm{MAPCO}_{2}$ system is paired with estimated $A_{\mathrm{T}}, \Omega_{\text {arag: }} p \mathrm{CO}_{2}$-AT also meets this uncertainty target (Table 3); however, natural variability of surface ocean $\Omega_{\text {arag: }} p \mathrm{CO}_{2}$-AT may be underestimated as discussed previously. This estimated uncertainty is likely higher during the months of May through July at the Gulf of Maine mooring site, where $\mathrm{SSS}<3025 \%$ of the time due to freshwater inputs; at low salinity, the $A_{\mathrm{T}}-\mathrm{SSS}$ relationship likely deteriorates. Total relative uncertainty of $\Omega_{\text {arag }}$ for all mooring data sets, averaged from the $\Omega_{\text {arag: }} p \mathrm{CO}_{2}-\mathrm{pH}$ and $\Omega_{\text {arag: }} p \mathrm{CO}_{2}-\mathrm{AT}$ data sets, likely falls between 5 and $10 \%$ (at the seawater conditions described in Table 3) and within the target relative uncertainty for describing short-term ocean acidification variability. From this point on, $\Omega_{\text {arag }}$ reported here is $\Omega_{\text {arag: }} p \mathrm{CO}_{2}$-AT for the WHOTS mooring time series and averaged $\Omega_{\text {arag: }} p \mathrm{CO}_{2}$-pH and $\Omega_{\text {arag: }} p \mathrm{CO}_{2}$-AT for the other mooring time series.

\section{Results and discussion}

\subsection{Observations of variability and change}

Direct observations of $p\left(\mathrm{CO}_{2}\right)$ and $\mathrm{pH}$ revealed present-day conditions of surface ocean carbonate chemistry in 12 different oceanic and coastal systems. The open ocean moor- 
ing time series sites are located in subtropical oligotrophic regions (WHOTS, Stratus), biologically productive subtropical regions that experience seasonal monsoons (BOBOA) and tropical cyclones (KEO), and subarctic regions with pronounced seasonality of physical and biological conditions (Papa, Iceland). Annual mean $\Omega_{\mathrm{arag}}$ at these sites ranged from 1.83 to 3.56 ; annual mean $\mathrm{pH}$ ranged from 7.99 to 8.12 (Figs. 1-4, Table 4). High biological productivity is a feature at each of the four coastal mooring time series sites on the continental shelves of the US east (Gulf of Maine, Gray's Reef) and west (CCE2, Chá bă) coasts. Summer upwelling is another important driver of conditions at Chá bă, located mid-shelf at $100 \mathrm{~m}$ bottom depth offshore of La Push, Washington (Alford et al., 2012). While upwelling can also impact the CCE2 site located mid-shelf at $800 \mathrm{~m}$ bottom depth farther south in the CCE, this subregion in particular has shown sensitivity to climatic drivers, such as the El Niño-Southern Oscillation (ENSO; Nam et al., 2011). Seasonal temperature and freshwater inputs impact natural variability at the two coastal moorings in the Atlantic with the Gulf of Maine site located $10 \mathrm{~km}$ from shore at $65 \mathrm{~m}$ bottom depth (Salisbury et al., 2009) and Gray's Reef $70 \mathrm{~km}$ from shore at $20 \mathrm{~m}$ bottom depth (Xue et al., 2016). The Chuuk and La Parguera sites are located in coral reef ecosystems within a semi-closed atoll lagoon in Micronesia at $23 \mathrm{~m}$ bottom depth and a patch reef in the Caribbean Sea southwest of Puerto Rico at $5 \mathrm{~m}$ bottom depth, respectively. Despite the more variable coastal and coral reef conditions, the range of annual mean $\Omega_{\text {arag }}$ at these sites was 1.97 to 3.37 , less than the range observed at the more diverse set of ocean regimes represented by the open ocean sites (Figs. 1, 5-7, Table 4). However, the range of annual mean $\mathrm{pH}$ was approximately the same as the open ocean sites from 8.01 to 8.15 (Figs. 5-7).

Of the open ocean time series, the moorings located in subtropical oligotrophic regions, WHOTS and Stratus, experienced lower seasonal to subseasonal variability in surface $\mathrm{pH}$ and $\Omega_{\text {arag }}$ (Figs. 2-4). Consistent trade winds and shallow mixed layer depth throughout the year along with the lack of deep winter convection likely contribute to this relatively low open ocean variability. Temporal variability was higher at the other four open ocean mooring locations, which was likely driven by (1) more prevalent seasonal changes in SST (on average 2 times more variable than WHOTS and Stratus) and productivity, and (2) stochastic events such as storms and typhoons. In general, the range of variability tended to be consistent throughout the annual cycle at each of the open ocean sites with exceptions of increased variability at the Iceland location in late summer and early fall and at Papa during winter (Fig. 4). Present-day $\Omega_{\text {arag }}$ values were mostly $>3$ yearround at the subtropical open ocean sites except at Stratus,

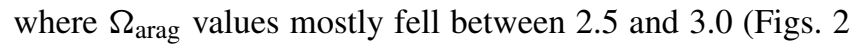
and 3). Surface $\Omega_{\text {arag }}$ conditions were further reduced at Papa and Iceland, the subarctic sites, which range from 1.5 to 2.5 (Fig. 4). Present-day $\mathrm{pH}$ observations were $>8$ throughout the average year at these mooring sites except at Stratus, where $\mathrm{pH}$ fell below 8 half the year from December through May (Fig. 2). Moored observations were consistent with seasonal means from ship-based time series observations at the WHOTS and Iceland sites (Bates et al., 2014).

The seasonal cycle of surface ocean $\Omega_{\mathrm{arag}}$ and $\mathrm{pH}$ were not always consistent with one another. Seawater $\Omega_{\text {arag }}$ is largely determined by variations in the concentration of the carbonate ion $\left(\mathrm{CO}_{3}^{2-}\right) ; \mathrm{pH}$ is influenced by gas exchange of $\mathrm{CO}_{2}$, physical conditions, and biological activity. Observations of surface ocean $\mathrm{pH}$ were consistent with a seasonal thermodynamic response, i.e., $\mathrm{pH}$ decrease (increase) with SST increase (decrease), at the four subtropical open ocean sites and at the Papa mooring (Figs. 2-4). However, this strong relationship was not consistent at the subarctic Iceland site. At this site, pH and SST were positively correlated (Fig. 4), suggesting that the seasonality of surface ocean $\mathrm{pH}$ was dominated by biological activity in the summer and/or winter mixing of upwelled deep water low in temperature and $\mathrm{pH}$ (Takahashi et al., 1993; Chen et al., 2007). At all open ocean sites, $\Omega_{\text {arag }}$ was highest during summer months, which led to the timing of low $\Omega_{\text {arag }}$ and low $\mathrm{pH}$ conditions to be anticorrelated over the annual cycle at all open ocean sites except Iceland (Figs. 2-4). This pattern at the Iceland mooring was consistent with seasonality of surface $\Omega_{\text {arag }}$ and $\mathrm{pH}$ derived from quarterly ship-based observations at the same site (Bates et al., 2014; Olafsson et al., 2009).

Comparisons to preindustrial bounds of variability also revealed differences between open ocean sites. All open ocean sites experienced surface $\Omega_{\text {arag }}$ outside the bounds of preindustrial variability year-round with the exception of BOBOA and Iceland. Present-day surface $\Omega_{\text {arag }}$ conditions still partially overlapped with preindustrial conditions at BOBOA during the monsoon season from June through August (Fig. 3), at Iceland during the summer to fall transition in August and September (Fig. 4), and slightly at KEO during November and December (Fig. 3). However, presentday surface $\mathrm{pH}$ observations fall completely outside preindustrial $\mathrm{pH}$ conditions at all open ocean sites year-round, except at BOBOA where there was a slight overlap of $4 \%$ in August (Figs. 2-4).

The coastal mooring sites experienced higher subseasonal to seasonal variability in surface $\mathrm{pH}$ and $\Omega_{\text {arag }}$ compared to the open ocean sites (Figs. 5 and 6). Each coastal time series exhibited clear seasonal patterns with annual amplitudes of $\Omega_{\text {arag }}$ ranging from 0.66 to 1.32 (Table 4). Gray's Reef and Chá bă experienced the highest subseasonal to seasonal variability in surface $\mathrm{pH}$ and $\Omega_{\mathrm{arag}}$, likely driven by upwelling/relaxation/downwelling dynamics that can change rapidly at Chá bă (Alford et al., 2012; Hickey and Banas, 2003) and high productivity and freshwater inputs in the spring and fall at Gray's Reef (Salisbury et al., 2009; Xue et al., 2016). We also observed the lowest pH values (7.8) and surface $\Omega_{\text {arag }}$ values close to undersaturation $\left(\Omega_{\mathrm{arag}}<1\right)$ primarily in the winter at Chá bă and in the spring at CCE2 (Fig. 5). These observations of near-undersaturated 
Table 4. Descriptive statistics of $\Omega_{\text {arag }}$ : annual mean, annual amplitude, and $1 \mathrm{SD}$ of annual anomalies from the $\mathrm{CO}_{2}$ and $\mathrm{pH}$ mooring observations, from a global data synthesis of ship-based observations (Takahashi et al., 2014), and a biogeochemical model (Friedrich et al., 2012). Bold values represent values larger than observed values; italicized values represent values lower than observed values. ND signifies no data.

\begin{tabular}{|c|c|c|c|c|c|c|c|}
\hline $\begin{array}{l}\text { Open ocean } \\
\text { sites }\end{array}$ & $\begin{array}{r}\text { Annual } \\
\text { mean }\end{array}$ & $\begin{array}{r}\text { Annual } \\
\text { amplitude }\end{array}$ & $\begin{array}{l}\text { SD annual } \\
\text { anomalies }\end{array}$ & $\begin{array}{l}\text { Coastal and coral } \\
\text { reef sites }\end{array}$ & $\begin{array}{r}\text { Annual } \\
\text { mean }\end{array}$ & $\begin{array}{l}\text { Annual } \\
\text { amplitude }\end{array}$ & $\begin{array}{l}\text { SD annual } \\
\text { anomalies }\end{array}$ \\
\hline WHOTS & & & & Chá bă & & & \\
\hline Observations & 3.49 & 0.17 & 0.05 & Observations & 1.88 & 1.32 & 0.45 \\
\hline Global synthesis & 3.62 & 0.34 & & Global synthesis & 2.06 & 0.67 & \\
\hline Model & & 0.25 & 0.09 & Model & & ND & ND \\
\hline Stratus & & & & CCE2 & & & \\
\hline Observations & 2.67 & 0.13 & 0.07 & Observations & 2.53 & 0.76 & 0.31 \\
\hline Global synthesis & 2.98 & 0.37 & & Global synthesis & ND & ND & \\
\hline Model & & 0.35 & 0.11 & Model & & ND & ND \\
\hline BOBOA & & & & Gray's Reef & & & \\
\hline Observations & 3.52 & 0.20 & 0.13 & Observations & 3.25 & 1.09 & 0.37 \\
\hline Global synthesis & 3.59 & 0.24 & & Global synthesis & 3.09 & 0.95 & \\
\hline Model & & 0.15 & 0.06 & Model & & ND & ND \\
\hline Iceland & & & & Gulf of Maine & & & \\
\hline Observations & 1.70 & 0.71 & 0.22 & Observations & 1.86 & 0.64 & 0.24 \\
\hline Global synthesis & 1.77 & 0.64 & & Global synthesis & ND & ND & \\
\hline Model & & 0.45 & 0.16 & Model & & ND & ND \\
\hline Papa & & & & Chuuk K1 & & & \\
\hline Observations & 2.08 & 0.49 & 0.15 & Observations & 3.42 & 0.21 & 0.11 \\
\hline Global synthesis & 1.83 & 0.55 & & Global synthesis & 3.86 & 0.08 & \\
\hline Model & & 0.35 & 0.09 & Model & & 0.05 & 0.04 \\
\hline KEO & & & & La Parguera & & & \\
\hline Observations & 3.08 & 0.48 & 0.16 & Observations & 3.62 & 0.33 & 0.11 \\
\hline Global synthesis & 3.32 & 0.61 & & Global synthesis & 3.86 & 0.21 & \\
\hline Model & & 0.35 & 0.06 & Model & & 0.15 & 0.04 \\
\hline
\end{tabular}

conditions are consistent with other observations and models within the northern CCE where the Chá bă mooring resides (Harris et al., 2013; Hauri et al., 2013) and may indicate respiration in the absence of photosynthetic uptake typical of winter/non-bloom periods.

Unlike the subtropical open ocean mooring sites, seasonality of surface ocean $\mathrm{pH}$ at these coastal sites showed strong influence of factors other than SST and were not always

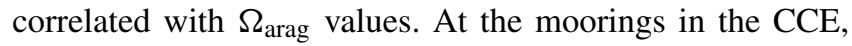
these parameters (i.e., SST, $\mathrm{pH}$, and $\Omega_{\mathrm{arag}}$ ) generally followed similar seasonal patterns, suggesting factors other than seasonal thermodynamic response influenced surface ocean $\mathrm{pH}$ (Fig. 5). However, surface ocean $\mathrm{pH}$ and $\Omega_{\text {arag }}$ did not always follow the same seasonal pattern at the Gray's Reef and Gulf of Maine mooring sites (Fig. 6). While SST likely influenced some of the seasonal variation in $\mathrm{pH}$ at these sites, biological activity and freshwater input also influenced seasonality of the carbonate system at these US east coast locations (Salisbury et al., 2009; Xue et al., 2016).

In general, the coastal sites experienced $\Omega_{\text {arag }}$ outside of the preindustrial range mainly during winter. One exception was Chá bă, the coastal site with the highest subseasonal variability (Fig. 5). This high subseasonal variability during spring through fall caused high month-to-month variability in the overlap with preindustrial conditions, suggesting this system may be on the threshold of a shift outside preindustrial conditions during this time of the year. Observations of pH at Chá bă followed this same pattern. In general, presentday observations of $\mathrm{pH}$ fell outside preindustrial conditions more so than $\Omega_{\text {arag }}$ at all coastal sites (Figs. 5 and 6).

Finally, similar to the coastal moorings, the coral reef mooring sites also experienced subseasonal to seasonal variability but not as large as within the subtropical coastal systems (Fig. 7). Mean annual $\Omega_{\text {arag }}$ at the Caribbean (La Parguera) and Pacific (Chuuk) moorings was 3.62 and 3.42, respectively, while mean $\mathrm{pH}$ was 8.02 and 8.01 , respectively (Fig. 7, Table 4). With the exception of low $\Omega_{\text {arag }}$ outliers at Chuuk, most $\Omega_{\text {arag }}$ conditions were $>3$ throughout the year at both sites, and surface $\mathrm{pH}$ observations were $>7.9$. The seasonal cycle of $\mathrm{pH}$ and $\Omega_{\text {arag }}$ was more pronounced at La Parguera with relatively consistent monthly range in variability, but the Chuuk site experienced greater variability December 


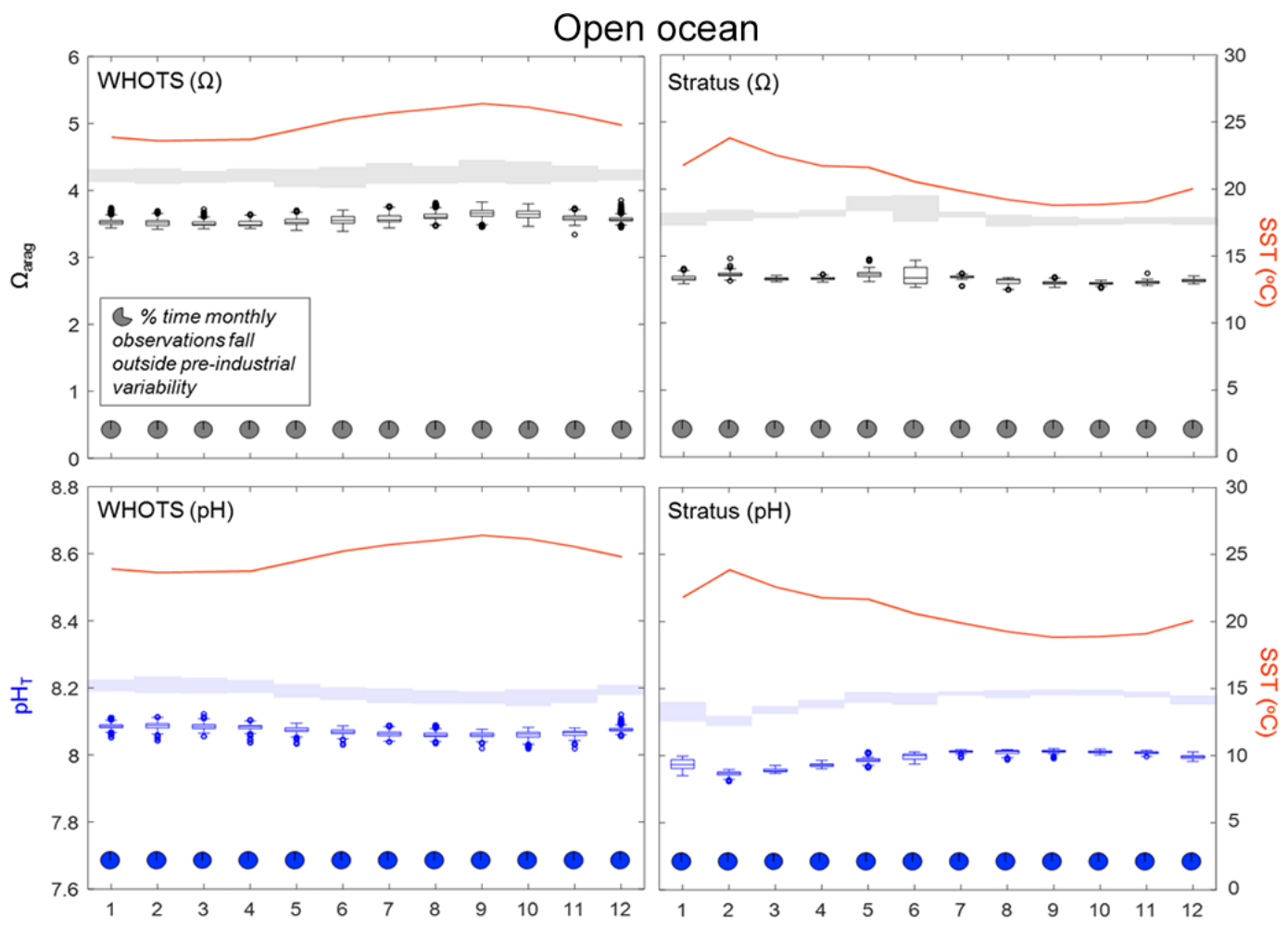

Figure 2. Box and whisker plots of present-day monthly surface seawater $\Omega_{\text {arag }}$ (top) and pH (bottom) and monthly mean SST (orange lines) at the open ocean mooring locations in subtropical oligotrophic regions (WHOTS, Stratus). Boxes represent data between Q1 and Q3, with the line between representing Q2 (i.e., the median). Whiskers represent 1.5 IQR, or $\sim 2.7 \mathrm{SD}$; Eqs. 1 and 2), of the upper and lower quartiles with data outside that range shown as outliers (open circles). Outliers here represent natural deviations in ocean chemistry, not measurement outliers, which were removed in the data quality control process. Estimated monthly preindustrial $\Omega_{\text {arag }}$ and $\mathrm{pH}$ variability (1.5 IQR or $\sim 2.7 \mathrm{SD}$ ) is shown in gray (top) and blue (bottom) shaded areas, respectively. Shaded portions of the pie charts indicate the percent of present-day $\Omega_{\text {arag }}$ and $\mathrm{pH}$ values falling outside the bounds of preindustrial variability for each month. For mooring location see Fig. 1 and Table 1.

through April, likely driven by local mixing during the trade winds season. Even with small seasonal fluctuations in tropical ocean temperature, both coral mooring sites did show patterns of $\mathrm{pH}$ and $\Omega_{\mathrm{arag}}$ seasonality associated with SST, with lower $\mathrm{pH}$ and $\Omega_{\text {arag }}$ values coinciding with slightly warmer summer months and higher $\mathrm{pH}$ and $\Omega_{\text {arag }}$ values during winter (Fig. 7). Present-day variability at these sites did not cause extensive overlap with preindustrial conditions. Present-day surface $\mathrm{pH}$ observations fell completely outside preindustrial conditions year-round at both coral reef sites (Fig. 7). Present-day $\Omega_{\text {arag }}$ conditions at La Parguera were largely outside of preindustrial bounds year-round, while this mainly occurred during the season of lowest variability from May to November at Chuuk (Fig. 7).

The results from these 12 mooring time series highlight the different patterns of variability of surface ocean $\Omega_{\text {arag }}$ and $\mathrm{pH}$ in both space and time. Figure 8 compares the relative influence of subseasonal, seasonal, and interannual variability at the mooring locations. Since the mooring observations were well distributed throughout the year, we are confident in the subseasonal and seasonal estimates of variability. How- ever, considering that most of the time series were only 2 to 5 years long, we expect to refine the estimates of interannual variability as we obtain more observations over the coming years. For example, ENSO is a driver of ocean conditions, including biogeochemistry, at CCE2 (Nam et al., 2011). While there were weak El Niño-like conditions that developed in the tropical Pacific in 2014 (McPhaden, 2015), there were no major La Niña or El Niño anomalies during the CCE2 time series used in this analysis (March 2012-2015). Hence, the estimate of interannual variability presented here is likely an underestimate of the true interannual signal at this location. In addition, this was a period of anomalously rapid warming in the Gulf of Maine, which may have caused $\Omega_{\text {arag }}$ to trend higher due the reduced solubility of $\Omega_{\mathrm{arag}}$ in warmer waters (Mills et al., 2013; Pershing et al., 2015). Potential variations in warming trends over time would also impact interannual variability of $\Omega_{\text {arag }}$ observations in the Gulf of Maine as the time series continues.

The coastal sites generally experienced higher subseasonal to interannual $\Omega_{\text {arag }}$ variability than the open ocean and coral reef sites. Relative to other patterns of variability, interan- 


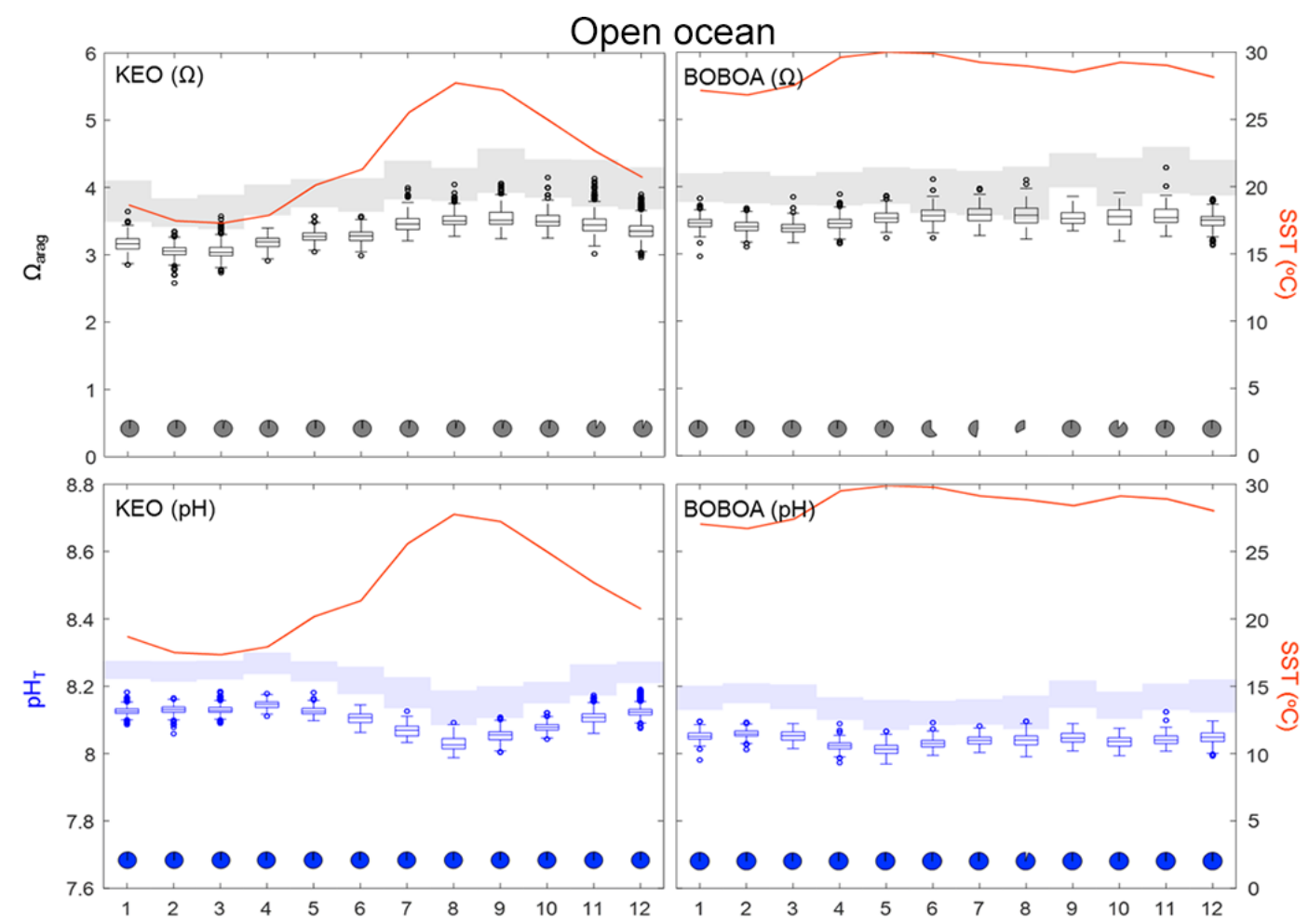

Figure 3. Box and whisker plots of present-day monthly surface seawater $\Omega_{\text {arag }}$ (top) and pH (bottom) and monthly mean SST at the open ocean mooring locations in biologically productive subtropical regions that experience seasonal monsoons (BOBOA) and tropical cyclones (KEO). See detailed description of figure components in Fig. 2 caption.

nual $\Omega_{\text {arag }}$ variability tended to be low at all sites except for at Chá bă, Gray's Reef, and CCE2 (Fig. 8a). The other sites tended to be equally influenced by subseasonal and seasonal variability with the exception of the Iceland mooring site, which was controlled more by seasonal variability over the annual cycle (Fig. 8a); however, subseasonal variability played a large role in August through October (Fig. 4). For $\mathrm{pH}$, most mooring sites exhibited similar patterns of variability with low interannual variability and approximately equal influence from seasonal and subseasonal variability (Fig. 8b). Similar to $\Omega_{\text {arag }}$, Chá bă, Gray's Reef, and CCE2 were the clear outliers with the highest values of interannual $\mathrm{pH}$ variability.

\subsection{Biologically relevant $\Omega_{\text {arag }}$ thresholds}

Research on response of shellfish larvae living in nearshore environments of the CCE and Gulf of Maine to changes in carbonate chemistry allowed us to investigate when observations at the Chá bă, CCE2, and Gulf of Maine moorings exceeded biological thresholds. Crassostrea gigas, the Pacific oyster whose larvae are raised in hatcheries in coastal Washington and Oregon, has shown sublethal impacts on larval development, such as shell development and growth, when exposed to levels of $\Omega_{\mathrm{arag}}<2.0$ (Barton et al., 2012) and acute impacts when $\Omega_{\text {arag }}<1.5$ (Waldbusser et al., 2015a, b). Other studies suggest that chronic exposure thresholds for the larvae of Ostrea lurida, the Olympia oyster, and Mytilus californianus, the California mussel, occur at $\Omega_{\text {arag }}<1.4$ (Hettinger et al., 2013) and $\Omega_{\text {arag }}<1.8$ (Gaylord et al., 2011), respectively. All of these shellfish larvae, whether naturally occurring or hatchery raised, are found in coastal environments in the region of the Chá bă mooring and M. californianus also exist farther south in the nearshore region of the CCE2 mooring. In addition, larvae of Mya arenaria, the soft-shell clam commercially harvested on tidal mudflats of the western Gulf of Maine, has shown a lack of shell formation and growth in laboratory experiments at $\Omega_{\text {arag }}<1.6$ (Salisbury et al., 2008).

Monthly climatology of $\Omega_{\text {arag }}$ developed from the mooring observations at Chá bă suggest that present-day $\Omega_{\text {arag }}$ conditions reached chronic exposure levels for $C$. gigas larvae $\left(\Omega_{\text {arag }}<2.0\right)$ over $50 \%$ of the time from November to March, with nearly the entire months of December through

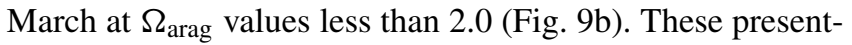
day conditions prevailed over more of the year compared to preindustrial times, when the most extensive chronic exposure occurred only up to $64 \%$ during March (Fig. 9a). Conditions that cause acute responses in $C$. gigas larvae $\left(\Omega_{\text {arag }}<1.5\right)$ were minimal year-round at Chá bă except for March, when these conditions persisted in the present day during $37 \%$ of the month (Fig. 9b) and only $14 \%$ of the month during preindustrial times (Fig. 9a). A similar sea- 


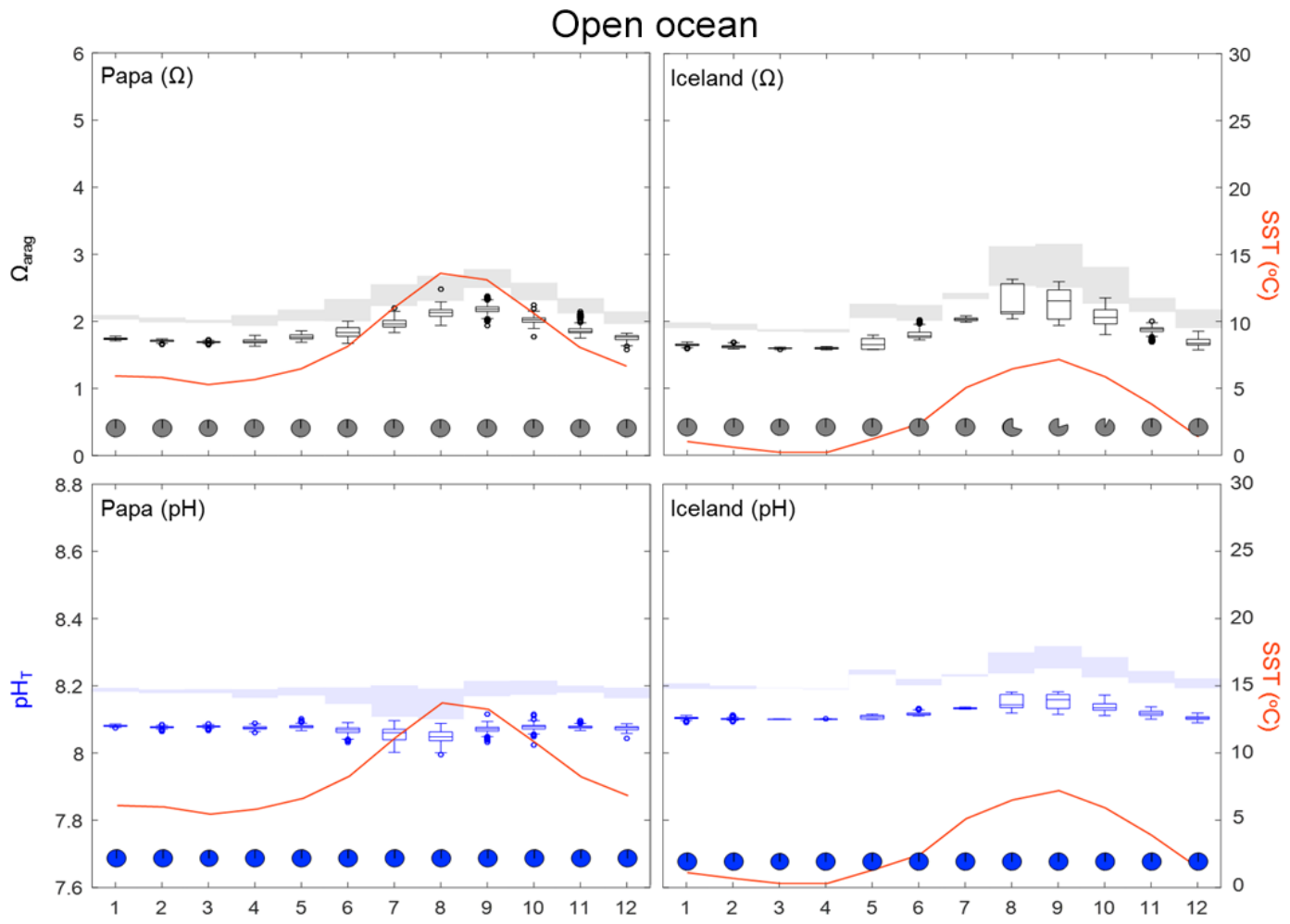

Figure 4. Box and whisker plots of present-day monthly surface seawater $\Omega_{\text {arag }}$ (top) and $\mathrm{pH}$ (bottom) and monthly mean SST at the open ocean mooring locations in subarctic regions with pronounced seasonality of physical and biological conditions (Papa, Iceland). See detailed description of figure components in Fig. 2 caption.

sonal pattern also existed for $O$. lurida larvae $\left(\Omega_{\mathrm{arag}}<1.4\right)$, when chronic exposure levels in March exceeded $27 \%$ during the present (Fig. 9b) compared to only $11 \%$ during preindustrial times (Fig. 9a). For M. californianus larvae, presentday chronic exposure levels $\left(\Omega_{\text {arag }}<1.8\right)$ prevailed over $40 \%$ of the time in January through March at Chá bă, while there was less chronic exposure at CCE2, at 11 to $38 \%$ of time in March through July (Fig. 9b). In both cases, present-day exceedance of these thresholds prevailed over fewer months and at a smaller percentage of the time during those months (Fig. 9a). For M. arenaria, present-day $\Omega_{\text {arag }}$ conditions exceeded chronic exposure levels at the Gulf of Maine mooring between 11 and $31 \%$ of the time during December through April, with peak exposure levels in February and March (Fig. 9b). In contrast to the CCE, which experienced corrosive $\Omega_{\text {arag }}$ conditions before ocean acidification, Gulf of Maine surface water conditions did not exceed biological thresholds for $M$. arenaria at any point during the year in preindustrial times (Fig. 9a).

These observations suggest that present-day coastal $\Omega_{\text {arag }}$ conditions exceeded thresholds for sublethal effects on shellfish larvae in the Gulf of Maine and during both presentday and preindustrial times at Chá bă and CCE2. However, present-day coastal conditions surpass these thresholds more often than preindustrial times (Fig. 9). In some cases, un- favorable surface ocean $\Omega_{\text {arag }}$ conditions overlap with the spawning season. Coastal conditions of $\Omega_{\mathrm{arag}}<1.4$ at Chá bă do not currently occur during the May to August $O$. lurida larvae spawning season. M. californianus tends to spawn year-round, and while natural populations of $C$. gigas do exist in Washington coastal waters and tend to spawn in the late summer, hatcheries raise $C$. gigas larvae year-round. Mooring observations suggest that present-day chronic exposure effects on $M$. californianus larvae may be more common in the winter in the northern CCE and in the spring in the southern CCE (Fig. 9). The summer spawning season of natural populations of $C$. gigas avoids chronic and acute exposure levels during winter months; however, hatcheries may encounter these conditions if raising larvae during this time. In the Gulf of Maine, M. arenaria spawns when seawater temperatures reach $10^{\circ} \mathrm{C}$, which during the moored time series occurred in May through November (Fig. 6). According to the Gulf of Maine mooring observations through 2013, corrosive conditions of $\Omega_{\mathrm{arag}}<1.6$ did not occur during this spawning season (Fig. 9b). However, maximum SST observations in April of $9.7^{\circ} \mathrm{C}$ were at the verge of this spawning threshold, and rapid warming in the Gulf of Maine of $0.23^{\circ} \mathrm{Cyr}^{-1}$ since 2004 suggests that SST as of April 2015 may have exceeded $10^{\circ} \mathrm{C}$ at the mooring site (Mills et al., 2013; Pershing et al., 2015). If this warming causes 


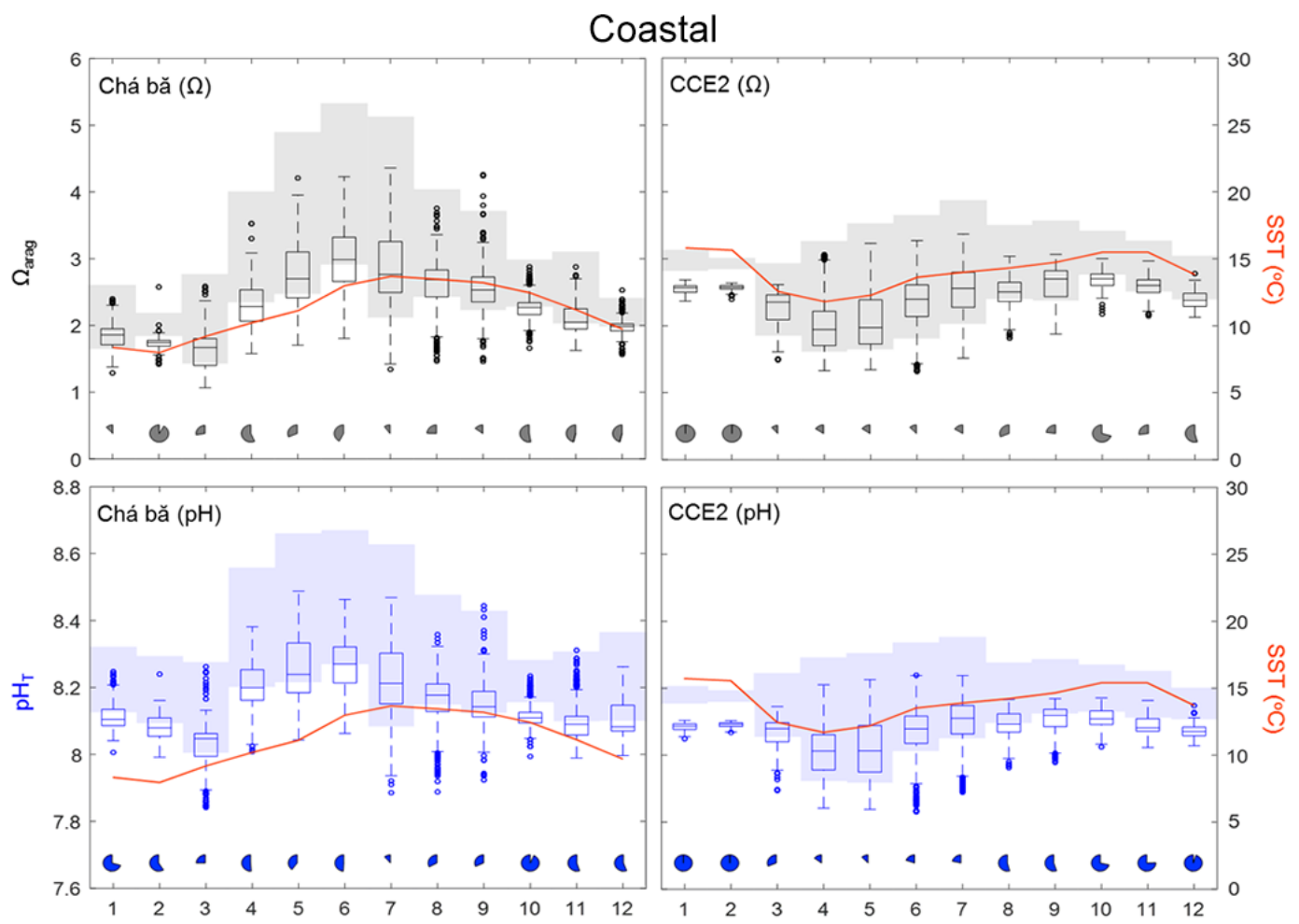

Figure 5. Box and whisker plots of present-day monthly surface seawater $\Omega_{\text {arag }}$ (top) and pH (bottom) and monthly mean SST at the coastal mooring locations on the continental shelves of the US west coast (CCE2, Chá bă). See detailed description of figure components in Fig. 2 caption.

M. arenaria to begin spawning in April, larvae may become exposed to $\Omega_{\text {arag }}$ conditions that limit shell formation and growth (Fig. 9b).

While these observations on the continental shelf were offshore from the inshore habitats where natural populations of shellfish and oyster hatcheries exist, these results provide valuable information on endmember coastal conditions that affect the nearshore regions. These monthly climatologies suggest surface water conditions corrosive to shellfish larvae presently exist year-round in the CCE (primarily during winter/spring) and during winter/spring in the Gulf of Maine. For shellfish hatcheries that utilize real-time coastal ocean acidification data and monitor conditions within their facilities, managing the impacts of these corrosive conditions on larvae may be possible. These climatologies may also inform the development of experiments testing the vulnerability of shelled organisms in other coastal regions. For example, target species may include ecologically or economically important species that undergo critical life stages when low $\Omega_{\text {arag }}$ conditions persist during spring in the region around Gray's Reef (Fig. 6). However, the coastal mooring climatologies also illustrate that low $\Omega_{\text {arag }}$ and low $\mathrm{pH}$ conditions do not always coincide in the natural environment, and experiments testing how $\Omega_{\text {arag }}, \mathrm{pH}$, and other stressors independently affect marine organisms are necessary for understanding ocean acidification impacts under the diversity of present-day conditions (Breitburg et al., 2015).

\subsection{Comparison to models and ship-based data syntheses}

Since high-frequency autonomous ocean acidification time series are relatively new, much of our current knowledge about ocean carbonate variability comes from ship-based observations. Due to the limitations of ship-based oceanography, these observations can have a seasonal measurement bias leading to errors in seasonal climatology estimates and only capture opportunistic stochastic events, which has resulted in limited knowledge about the influence of subseasonal processes on ocean carbonate variability. In general, we found fairly good agreement between annual mean mooring $\Omega_{\text {arag }}$ observations and annual mean ship-based data syntheses, which primarily used repeat hydrographic cruise data from the Global Data Analysis Project (Key et al., 2004). Both the Jiang et al. (2015) and Takahashi et al. (2014) data syntheses overestimated surface ocean $\Omega_{\text {arag }}$ at the Stratus mooring in the South Pacific by 0.31 (Fig. 1; Table 4). Undersampling likely contributed to this discrepancy. Moored observations revealed the lowest $\Omega_{\text {arag }}$ conditions during August through October; however, ship-based observations were lacking in this region of the Southern Hemisphere dur- 


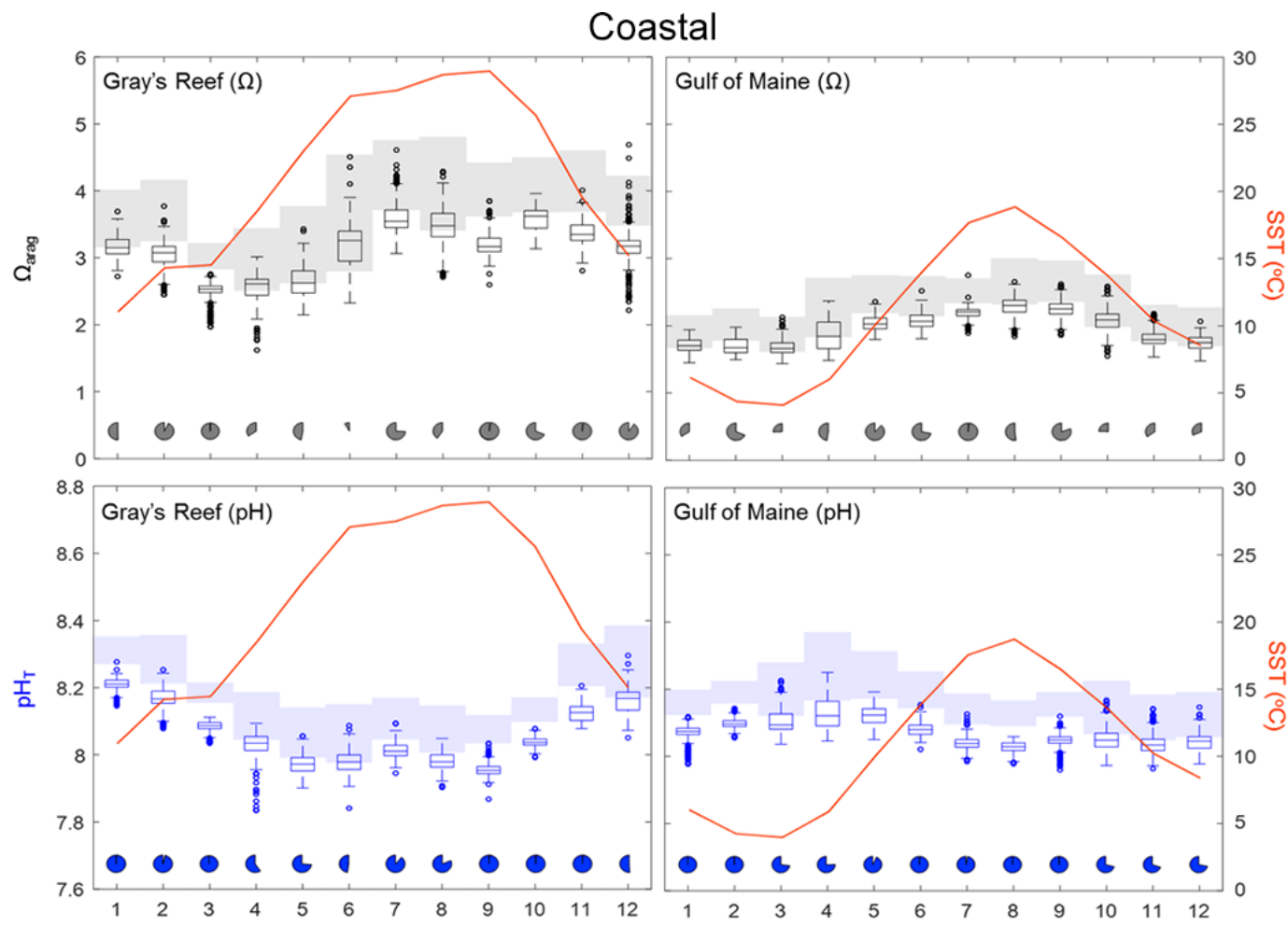

Figure 6. Box and whisker plots of present-day monthly surface seawater $\Omega_{\text {arag }}$ (top) and pH (bottom) and monthly mean SST at the coastal mooring locations on the continental shelves of the US east coast (Gulf of Maine, Gray's Reef). See detailed description of figure components in Fig. 2 caption.

ing this season. Annual mean surface $\Omega_{\text {arag }}$ at the four US coastal mooring sites tended to reflect mean open ocean conditions characterized by the ship-based data synthesis presented in Fig. 1; however, direct observations in the two coral reef environments suggest that open ocean carbonate chemistry was modified on the reefs and in these two cases, resulted in reduced annual mean $\Omega_{\text {arag }}$ compared to the ship-based data syntheses (Fig. 1; Table 4). The shipbased data syntheses also slightly overestimated annual mean $\Omega_{\text {arag }}$ at WHOTS, KEO, BOBOA, Iceland, and Chá bă; however, these overestimations were roughly within the change in $\Omega_{\text {arag }}$ expected between the time of the mooring observations (typically 2010-2015) and the ship-based observations (adjusted to a reference year of 2000 by Jiang et al., 2015 and 2005 by Takahashi et al., 2014). Assuming a global average rate of change of surface ocean $\Omega_{\mathrm{arag}}$ of $-0.008 \mathrm{yr}^{-1}$ (Bates et al., 2014), the change over this $5-15$ year period would be $0.04-0.12$.

Of the 10 mooring locations with observations presented in the Takahashi et al. (2014) data synthesis, seasonal variability was overestimated by the ship-based observations at all open ocean sites except Iceland, and underestimated at Iceland and the coastal and coral reef sites (Table 4). These differences could be driven by sparse ship-based data in space and time used to estimate climatological seasonal vari- ability in the Takahashi et al. (2014) synthesis. This analysis demonstrates that in addition to new information about subseasonal variability that is not captured by ship-based observations, moored observations can also be used to improve ship-based data synthesis estimates of seasonal to annual $\Omega_{\text {arag }}$ conditions in undersampled regions such as the Southern Hemisphere, Iceland Sea, and coastal systems.

Overall, earth system models tend to underestimate natural variability of the carbonate system. The series of earth system models used by Friedrich et al. (2012) underestimated both seasonal and interannual variability of surface $\Omega_{\text {arag }}$ at all mooring locations except for WHOTS and Stratus, which were the sites with the lowest variability (Table 4). These underestimations are expected at the coastal and coral sites since the models do not capture small-scale biogeochemical processes occurring in these environments. When Friedrich et al. (2012) extrapolated an average annual $\Omega_{\text {arag }}$ amplitude of $\sim 0.1$ in subtropical oligotrophic open ocean regions to coral locations, they concluded that present-day coral conditions fell 5 times outside the preindustrial range of variability. However, we found that actual seasonal variability was 2 to 3 times higher than 0.1 at the Chuuk and La Parguera mooring locations (Table 4 ), and present-day $\Omega_{\text {arag }}$ conditions were only 1 to 2 times below the preindustrial range of variability (Fig. 7). On the other hand, we found CCSM3- 


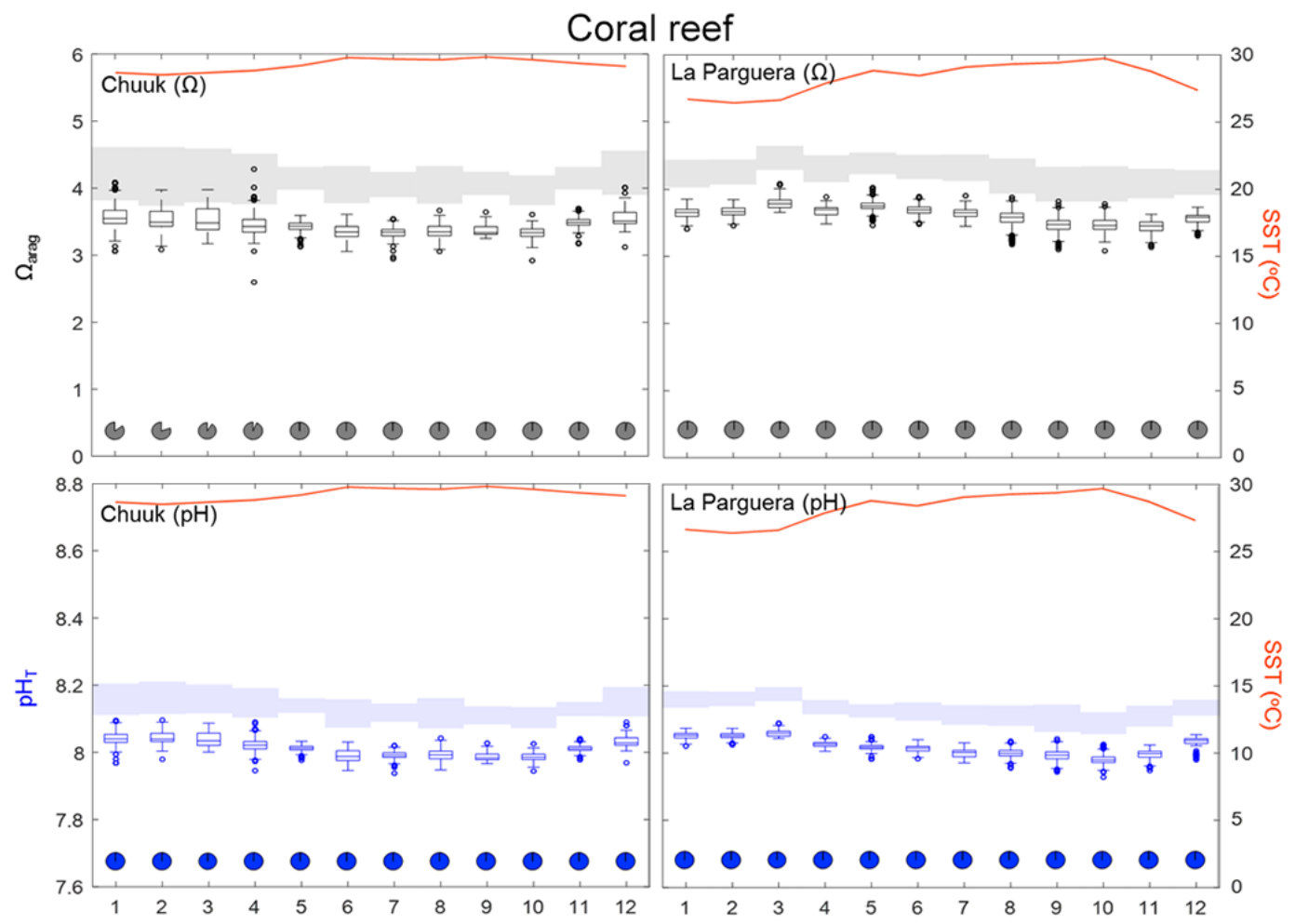

Figure 7. Box and whisker plots of present-day monthly surface seawater $\Omega_{\text {arag }}$ (top) and pH (bottom) and monthly mean SST in coral reef ecosystems within a semi-closed atoll lagoon in Micronesia (Chuuk) and a patch reef in the Caribbean Sea southwest of Puerto Rico (La Parguera). See detailed description of figure components in Fig. 2 caption.

based estimates of preindustrial envelop exceedance by Cooley et al. (2009) to be conservative in some regions. They found that by 2050 all regions will experience surface $\Omega_{\mathrm{arag}}$ conditions outside preindustrial bounds of variability with emphasis in low-latitude regions. Our present-day mooring observations suggest that not only has the shift outside of preindustrial conditions already occurred year-round at the low-latitude coral reef sites, but also at subtropical and subarctic open ocean sites.

Some state-of-the-art earth system models have improved the characterization of background natural variability in the open ocean. A recent study found that global mean surface ocean $\mathrm{pH}$ conditions ( $\Omega_{\text {arag }}$ not assessed) moved outside preindustrial bounds of variability by 2008 (Mora et al, 2013), which is more consistent with the open ocean moored observations (Figs. 2-4) compared to the CCSM3-based estimates (Cooley et al., 2009). Newer earth systems models may still underestimate the full magnitude of variability; however, they can illustrate the relative variability signal between different open ocean regions (Rodgers et al., 2015). Similar to the moored observations, Rodgers et al. (2015) showed that $\Omega_{\text {arag }}$ variability is higher in the North Pacific and North Atlantic regions (KEO, Papa, Iceland) compared to subtropical and tropical regions (i.e., WHOTS, Stratus, BOBOA).
Unlike global earth system models, some regional models are able to resolve small-scale coastal processes and may provide better estimates of natural variability in these dynamic systems. We found the highest levels of natural variability at the Chá bă mooring location with an annual range of surface ocean $\Omega_{\text {arag }}$ of 3.3, from $\Omega_{\text {arag }}$ values of 1.06 to 4.36 (Fig. 5). Estimates of this range for the northern CCE produced by a regional model were only 0.2 , which led to the conclusion that surface ocean $\Omega_{\text {arag }}$ conditions in 2005 were already outside the bounds of preindustrial conditions (Hauri et al., 2013). Observations at Chá bă from 2010 to 2014 suggest conditions only fell partially outside preindustrial variability, primarily during the lower variability season from October to February (Fig. 5).

\section{Conclusions}

Direct, high-resolution observations of seawater $p\left(\mathrm{CO}_{2}\right)$ and $\mathrm{pH}$ reveal that marine life is currently exposed to surface ocean $\mathrm{pH}$ and $\Omega_{\mathrm{arag}}$ values outside the envelope of preindustrial variability that they have adapted to at all 12 study locations. Marine life at several study locations is also exposed to conditions exceeding thresholds that may impact the growth and survival of shellfish and conditions approaching undersaturation $\left(\Omega_{\mathrm{arag}}<1\right)$. These ocean acidification im- 
(a) $\Omega_{\text {arag }}$
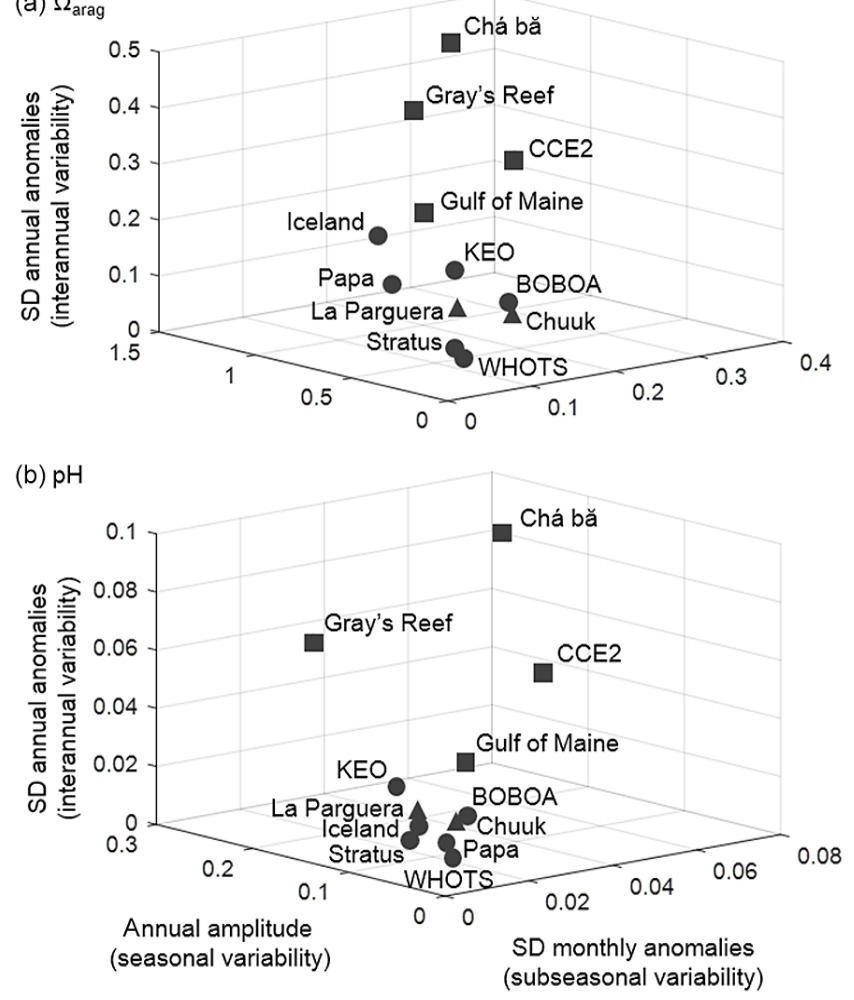

Figure 8. Relational plot of different modes of (a) $\Omega_{\text {arag }}$ and (b) $\mathrm{pH}$ variability for each ocean acidification mooring location. Statistics describing variability include $1 \mathrm{SD}$ of monthly anomalies (monthly mean - monthly observations), annual amplitude (maximum monthly climatological mean - minimum monthly climatological mean), and $1 \mathrm{SD}$ of annual anomalies (annual mean mean observations). Circles represent open ocean mooring locations, squares denote coastal sites, and triangles denote coral reefs.

pacts are occurring at the same time that marine organisms are also experiencing different patterns of temporal variability and other anthropogenic stressors, which can be unique to distinct locations and seasons. This high-resolution mooring work provides a new perspective on variability, since earth system models and ship-based observations generally underestimate the temporal variability of surface ocean $\Omega_{\mathrm{arag}}$ conditions, especially in coastal regions. These results highlight the need to further interrogate these biases, which are often the basis for predictions of future ocean acidification impact. In most cases, such as the WHOTS mooring time series, ocean carbonate observations are also paired with additional autonomous physical and biogeochemical measurements at the surface and at depth, as well as long-term ship-based time series measurements, which are not as temporally resolved as the moored measurements but often include biogeochemical parameters that cannot be measured autonomously. Further synthesis of these data sets from multiple platforms will contribute to improving understanding of the biogeochemical processes controlling carbonate chemistry at these time se-

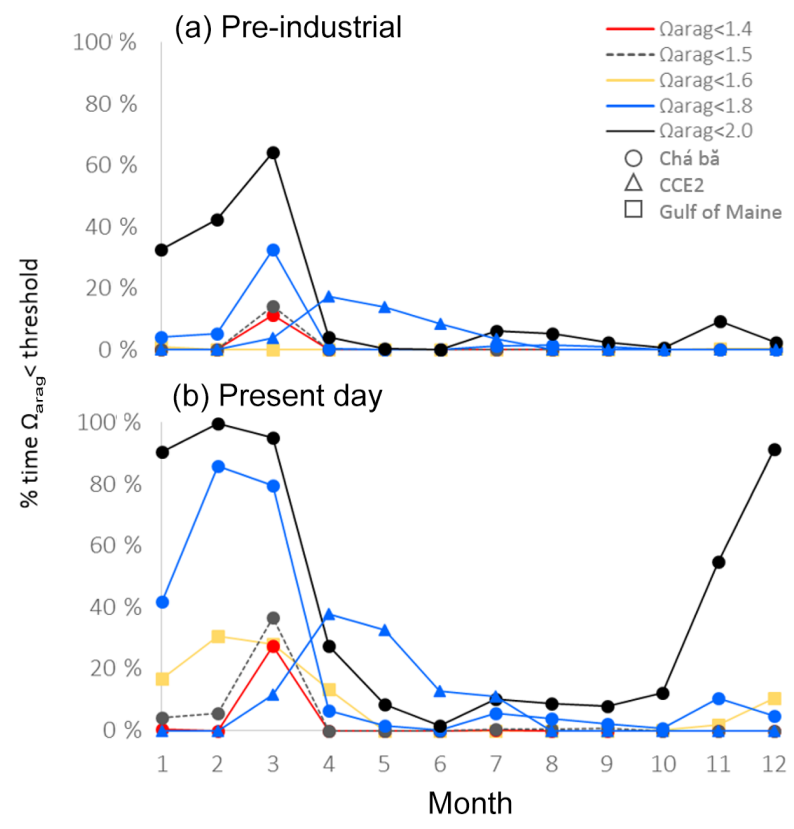

Figure 9. Percent time that (a) preindustrial and (b) present-day surface seawater $\Omega_{\text {arag }}$ conditions fall below biological thresholds: chronic exposure for Ostrea lurida larvae at $\Omega_{\mathrm{arag}}<1.4$ in red, acute effect of Crassostrea gigas larvae at $\Omega_{\text {arag }}<1.5$ in gray, chronic exposure for Mya arenaria larvae at $\Omega_{\mathrm{arag}}<1.6$ in gold, chronic exposure for Mytilus californianus larvae at $\Omega_{\mathrm{arag}}<1.8$ in blue, and chronic exposure for $C$. gigas larvae at $\Omega_{\text {arag }}<2.0$ in black. Thresholds at the Chá bă mooring are shown as circles; thresholds at the CCE2 mooring (only for $M$. californianus larvae) are shown as triangles; thresholds at the Gulf of Maine mooring (only for M. arenaria larvae) are shown as squares. The one acute threshold is indicated by a dashed line.

ries locations and to developing parameterizations for global and regional models. Here we focused on assessing ocean carbonate variability and change as a step in advancing these efforts; however, future research at these and other ocean acidification mooring sites should also include assessments of additional biogeochemical parameters, such as dissolved oxygen and optical properties, as these new observational data sets become available.

Sustained, autonomous observations resolving subseasonal conditions are likely to match timescales relevant to biological processes in the natural environment such as energy availability, biological threshold exceedance, seasonal spawning, and recruitment. This characterization of temporal variability of ocean carbonate is one of the major challenges to understanding how anthropogenic change will impact marine life. Impacts to marine life could manifest through one or a combination of the following environmental stressors: the slow, steady change over time as $\mathrm{pH}$ and $\Omega_{\text {arag }}$ conditions respond to gradual ocean uptake of anthropogenic $\mathrm{CO}_{2}$, the point in time when $\mathrm{pH}$ and $\Omega_{\mathrm{arag}}$ conditions leave the preindustrial envelope of variability to 
which organisms have adapted, when average or seasonal $\mathrm{pH}$ and $\Omega_{\text {arag }}$ conditions pass a certain threshold, or when episodic corrosive conditions surpass a tipping point in terms of frequency and duration. Our mooring time series exhibit periods of time when surface ocean $\mathrm{pH}$ and $\Omega_{\text {arag }}$ conditions fall outside preindustrial bounds of variability along with surpassing biologically relevant thresholds, but also time periods where none or only one of these stressors is present. A broad understanding of how this myriad of environmental stressors impact marine life will require a range of approaches including continued and expanded biogeochemical observing, research interrogating the fundamental processes underlying organism response to ocean acidification under laboratory and field conditions, experiments designed to address how different patterns of variability and change impact organisms, and paired chemical and biological observations in the field to assess potential present-day impacts. Characterizing natural variability and biological impact of ocean acidification conditions at key locations will also be fundamental to improving vulnerability assessments seeking to quantify the economic impact of ocean acidification at local to global scales.

\section{Data availability}

PMEL ocean carbon mooring data are archived at the Carbon Dioxide Information Analysis Center (CDIAC) and the National Centers for Environmental Information (NCEI). Finalized data sets can be found organized by mooring location by navigating through the clickable $\mathrm{CO}_{2}$ data portal map at http://cdiac.ornl.gov/oceans/Moorings/ or through the table of PMEL moorings at http://www.nodc.noaa.gov/ oceanacidification/stewardship/mooring_table.html.

Acknowledgements. The $\mathrm{CO}_{2}$ and ocean acidification observations were funded by NOAA's Climate Observation Division (COD) in the Climate Program Office and NOAA's Ocean Acidification Program. The maintenance of the Stratus and WHOTS Ocean Reference Stations were also supported by NOAA COD (NA09OAR4320129). Additional support for buoy equipment, maintenance, and/or ancillary measurements was provided by NOAA through the US Integrated Ocean Observing System office: for the La Parguera buoy under a Cooperative Agreement (NA11NOS0120035) with the Caribbean Coastal Ocean Observing System, for the Chá bă buoy under a Cooperative Agreement (NA11NOS0120036) with the Northwest Association of Networked Ocean Observing System, for the Gray's Reef buoy under a Cooperative Agreement (NA11NOS0120033) with the Southeast Coastal Ocean Observing Regional Association, and for the Gulf of Main buoy under a Cooperative Agreement (NA11NOS0120034) with the Northeastern Regional Association of Coastal and Ocean Observing Systems. Additional support for the Chuuk buoy was also provided by the NOAA-Korean Ministry of Oceans and Fisheries Joint Project Agreement. This $\mathrm{CO}_{2}$ and ocean acidification observation network would not be possible without the diligent efforts of PMEL technical and engineering staff, as well as current and former partners and their staff that support the maintenance of the buoys including: technical staff of the Upper Ocean Processes Group at the Woods Hole Oceanographic Institution and the crews of the NOAA and UNOLS vessels used for maintenance (WHOTS and Stratus); Jón Ólafsson and Héðinn Valdimarsson (Iceland); Chris O'Brien, Rudi Hermes, and Dave Zimmerman (BOBOA); John Mickett (Chá bă); Mark Ohman, Paul Chua, and David Glassier (CCE2); Yongchen Wang and Scott Noakes (Gray's Reef); Chris Hunt and Shawn Shellito (Gulf of Maine); Melissa Melendez Oyola (La Parguera); and Charity Lee and Seon Jeong Kim (Chuuk). A special thank you is expressed to Stacy Maenner-Jones, Randy Bott, Sylvia Musielewicz, John Osborne, and Colin Dietrich of the PMEL $\mathrm{CO}_{2}$ mooring team, who supported all aspects of data collection and quality control, and also to Li-Qing Jiang who provided the base map for Fig. 1. PMEL contribution 4435 and JISAO contribution 2506.

Edited by: J.-P. Gattuso

Reviewed by: three anonymous referees

\section{References}

Albright, R., Caldeira, L., Hosfelt, J., Kwiatkowski, L., Maclaren, J. K., Mason, B. M., Nebuchina, Y., Ninokawa, A., Pongratz, J., Ricke, K. L., Rivlin, T., Schneider, K., Sesboüé, M., Shamberger, K., Silverman, J., Wolfe, K., Zhu, K., and Caldeira, K.: Reversal of ocean acidification enhances net coral reef calcification, Nature, 531, 362-365, 2016.

Alford, M. H., Mickett, J. B., Zhang, S., MacCready, P., Zhao, Z., and Newton, J.: Internal waves on the Washington continental shelf, Oceanography, 25, 66-79, 2012.

Barton, A., Hales, B., Waldbusser, G. G., Langdon, C., and Feely, R. A.: The Pacific oyster, Crassostrea gigas, shows negative correlation to naturally elevated carbon dioxide levels: Implications for near-term ocean acidification effects, Limnol. Oceanogr., 57, 698-710, 2012.

Bates, N. R., Astor, Y. M., Church, M. J., Currie, K., Dore, J. E., González-Dávila, M., Lorenzoni, L., Muller-Karger, F., Olafsson, J., and Santana-Casiano, J. M.: A time-series view of changing ocean chemistry due to ocean uptake of anthropogenic $\mathrm{CO}_{2}$ and ocean acidification, Oceanography, 27, 126-141, 2014.

Bauer, J. E., Cai, W.-J., Raymond, P. A., Bianchi, T. S., Hopkinson, C. S., and Regnier, P. A. G.: The changing carbon cycle of the coastal ocean, Nature, 504, 61-70, 2013.

Bednaršek, N., Tarling, G. A., Fielding, S., and Bakker, D. C. E.: Population dynamics and biogeochemical significance of $\mathrm{Li}$ macina helicina antarctica in the Scotia Sea (Southern Ocean), Deep-Sea Res. Pt. II, 59-60, 105-116, 2012.

Bednaršek, N., Feely, R. A., Reum, J. C. P., Peterson, B., Menkel, J., Alin, S. R., and Hales, B.: Limacina helicina shell dissolution as an indicator of declining habitat suitability owing to ocean acidification in the California Current Ecosystem, P. Roy. Soc. Lond. B, 281, 20140123, doi:10.1098/rspb.2014.0123, 2014a.

Bednaršek, N., Tarling, G. A., Bakker, D. C. E., Fielding, S., and Feely, R. A.: Dissolution dominating calcification process in polar pteropods close to the point of aragonite undersaturation, 
PLoS ONE, 9, e109183, doi:10.1371/journal.pone.0109183, 2014b.

Breitburg, D. L., Salisbury, J., Bernhard, J. M., Cai, W. -J., Dupont, S., Doney, S. C., Kroeker, K. J., Levin, L. A., Long, W. C., Milke, L. M., Miller, S. H., Phelan, B., Passow, U., Seibel, B. A., Todgham, A. E., and Tarrant, A. M.: And on top of all that... Coping with ocean acidification in the midst of many stressors, Oceanography, 28, 48-61, 2015.

Cai, W.-J., Hu, X., Huang, W.-J., Murrell, M. C., Lehrter, J. C., Lohrenz, S. E., Chou, W.-C., Zhai, W., Hollibaugh, J. T., Wang, Y., Zhao, P., Guo, X., Gundersen, K., Dai, M., and Gong, G.-C.: Acidification of subsurface coastal waters enhanced by eutrophication, Nat. Geosci., 4, 766-770, 2011.

Caldeira, K. and Wickett, M. E.: Ocean model predictions of chemistry changes from carbon dioxide emissions to the atmosphere and ocean, J. Geophys. Res., 110, C09S04, doi:10.1029/2004jc002671, 2005.

Chen, F., Cai, W.-J., Benitez-Nelson, C., and Wang, Y.: Sea surface $p \mathrm{CO}_{2}$-SST relationships across a cold-core cyclonic eddy: Implications for understanding regional variability and air-sea gas exchange, Geophys. Res. Lett., 34, L10603, doi:10.1029/2006GL028058, 2007.

Cooley, S. R., Kite-Powell, H. L., and Doney, S. C.: Ocean acidification's potential to alter global marine ecosystem services, Oceanography, 22, 172-181, 2009.

Cullison Gray, S. E., DeGrandpre, M. D., Moore, T. S., Martz, T. R., Friederich, G. E., and Johnson, K. S.: Applications of in situ $\mathrm{pH}$ measurements for inorganic carbon calculations, Mar. Chem., 125, 82-90, 2011.

Dickson, A. G.: Standard potential of the reaction: $\mathrm{AgCl}(\mathrm{s})+1 / 2$ $\mathrm{H}_{2}(\mathrm{~g})=\mathrm{Ag}(\mathrm{s})+\mathrm{HCl}(\mathrm{aq})$, and the standard acidity constant of the ion $\mathrm{HSO}_{4}^{-}$in synthetic sea water from 273.15 to $318.15 \mathrm{~K}$, J. Chem. Thermodyn., 22, 113-127, 1990.

Dickson, A. G., Sabine, C. L., and Christian, J. R. (Eds.): Guide to Best Practices for Ocean $\mathrm{CO}_{2}$ Measurements, North Pacific Marine Science Organization (PICES), Sidney, British Columbia, Canada, 176 pp., 2007.

Ekstrom, J. A., Suatoni, L., Cooley, S. R., Pendleton, L. H., Waldbusser, G. G., Cinner, J. E., Ritter, J., Langdon, C., van Hooidonk, R., Gledhill, D., Wellman, K., Beck, M. W., Brander, L. M., Rittschof, D., Doherty, C., Edwards, P. E. T., and Portela, R.: Vulnerability and adaptation of US shellfisheries to ocean acidification, Nature Climate Change, 5, 207-214, doi:10.1038/nclimate2508, 2015.

Fassbender, A. J.: New approaches to study the marine carbon cycle, $\mathrm{PhD}$ dissertation, University of Washington, Seattle, Washington, USA, 142 pp., 2014.

Feely, R. A., Sabine, C. L., Lee, K., Berelson, W., Kleypas, J., Fabry, V. J., and Millero, F. J.: Impact of anthropogenic $\mathrm{CO}_{2}$ on the $\mathrm{CaCO}_{3}$ system in the oceans, Science, 305, 362-366, 2004.

Feely, R. A., Alin, S. R., Newton, J., Sabine, C. L., Warner, M., Devol, A., Krembs, C., and Maloy C.: The combined effects of ocean acidification, mixing, and respiration on $\mathrm{pH}$ and carbonate saturation in an urbanized estuary, Estuar. Coast. Shelf S., 88, 442-449, 2010.

Friedrich, T., Timmermann, A., Abe-Ouchi, A., Bates, N. R., Chikamoto, M. O., Church, M. J., Dore, J. E., Gledhill, D. K., Gonzalez-Davila, M., Heinemann, M., Ilyina, T., Jungclaus, J. H., McLeod, E., Mouchet, A., and Santana-Casiano, J. M.:
Detecting regional anthropogenic trends in ocean acidification against natural variability, Nature Climate Change, 2, 167-171, doi:10.1038/nclimate1372, 2012.

Garcia, H. E., Locarnini, R. A., Boyer, T. P., Antonov, J. I., Zweng, M. M., Baranova, O. K., and Johnson, D. R.: World Ocean Atlas 2009, Volume 4: Nutrients (phosphate, nitrate, silicate), in: NOAA Atlas NESDIS 71, edited by: Levitus, S., US Government Printing Office, Washington, DC, USA, 398 pp., 2010.

Gaylord, B., Hill, T. M., Sanford, E., Lenz, E. A., Jacobs, L. A., Sato, K. N., Russell, A. D., and Hettinger, A.: Functional impacts of ocean acidification in an ecologically critical foundation species, J. Exp. Biol., 214, 2586-2594, 2011.

Harris, K. E., DeGrandpre, M. D., and Hales, B.: Aragonite saturation state dynamics in a coastal upwelling zone, Geophys. Res. Lett., 40, 2720-2725, 2013.

Hauri, C., Gruber, N., Vogt, M., Doney, S. C., Feely, R. A., Lachkar, Z., Leinweber, A., McDonnell, A. M. P., Munnich, M., and Plattner, G.-K.: Spatiotemporal variability and long-term trends of ocean acidification in the California Current System, Biogeosciences, 10, 193-216, doi:10.5194/bg-10-193-2013, 2013.

Hettinger, A., Sanford, E., Hill, T. M., Lenz, E. A., Russell, A. D., and Gaylord, B.: Larval carry-over effects from ocean acidification persist in the natural environment, Glob. Change Biol., 19, 3317-3326, 2013.

Hickey, B. M. and Banas, N. S.: Oceanography of the US Pacific Northwest coastal ocean and estuaries with application to coastal ecology, Estuaries, 26, 1010-1031, 2003.

Hofmann, G. E., Smith, J. E., Johnson, K. S., Send, U., Levin, L. A., Micheli, F., Paytan, A., Price, N. N., Peterson, B., Takeshita, Y., Matson, P. G., Crook, E. D., Kroeker, K. J., Gambi, M. C., Rivest, E. B., Frieder, C. A., Yu, P. C., and Martz, T. R.: High-frequency dynamics of ocean $\mathrm{pH}$ : A multi-ecosystem comparison, PLoS ONE, 6, e28983, doi:10.1371/journal.pone.0028983, 2011.

Jiang, L.-Q., Feely, R. A., Carter, B. R., Greeley, D. J., Gledhill, D. K., and Arzayus, K. M.: Climatological distribution of aragonite saturation state in the global oceans, Global Biogeochem. Cy., 29, 1656-1673, 2015.

Kelly, R. P. and Caldwell, M. R.: Ten ways states can combat ocean acidification (and why they should), Harvard Environ. Law, 37, 57-103, 2013.

Kelly, R. P., Foley, M. M., Fisher, W. S., Feely, R. A., Halpern, B. S., Waldbusser, G. G., and Caldwell, M. R.: Mitigating local causes of ocean acidification with existing laws, Science, 332, 1036-1037, 2011.

Key, R. M., Kozyr, A., Sabine, C. L., Lee, K., Wanninkhof, R., Bullister, J. L., Feely, R. A., Millero, F. J., Mordy, C., and Peng, T. H.: A global ocean carbon climatology: Results from Global Data Analysis Project (GLODAP), Global Biogeochem. Cy., 18, GB4031, doi:10.1029/2004GB002247, 2004.

Khatiwala, S., Tanhua, T., Mikaloff Fletcher, S., Gerber, M., Doney, S. C., Graven, H. D., Gruber, N., McKinley, G. A., Murata, A., Ríos, A. F., and Sabine, C. L.: Global ocean storage of anthropogenic carbon, Biogeosciences, 10, 2169-2191, doi:10.5194/bg-10-2169-2013, 2013.

Lee, K., Tong, L. T., Millero, F. J., Sabine, C. L., Dickson, A. G., Goyet, C., Park, G.-H., Wanninkhof, R., Feely, R. A., and Key, R. M.: Global relationships of total alkalinity with salinity and temperature in surface waters of the world's oceans, Geophys. Res. Lett., 33, L19605, doi:10.1029/2006GL027207, 2006. 
Lee, K., Kim, T.-W., Byrne, R. H., Millero, F. J., Feely, R. A., Liu, and Y.-M.: The universal ratio of boron to chlorinity for the North Pacific and North Atlantic oceans, Geochim. Cosmochim. Ac., 74, 1801-1811, 2010.

Le Quéré, C., Moriarty, R., Andrew, R. M., Canadell, J. G., Sitch, S., Korsbakken, J. I., Friedlingstein, P., Peters, G. P., Andres, R. J., Boden, T. A., Houghton, R. A., House, J. I., Keeling, R. F., Tans, P., Arneth, A., Bakker, D. C. E., Barbero, L., Bopp, L., Chang, J., Chevallier, F., Chini, L. P., Ciais, P., Fader, M., Feely, R. A., Gkritzalis, T., Harris, I., Hauck, J., Ilyina, T., Jain, A. K., Kato, E., Kitidis, V., Klein Goldewijk, K., Koven, C., Landschützer, P., Lauvset, S. K., Lefèvre, N., Lenton, A., Lima, I. D., Metzl, N., Millero, F., Munro, D. R., Murata, A., Nabel, J. E. M. S., Nakaoka, S., Nojiri, Y., O'Brien, K., Olsen, A., Ono, T., Pérez, F. F., Pfeil, B., Pierrot, D., Poulter, B., Rehder, G., Rödenbeck, C., Saito, S., Schuster, U., Schwinger, J., Séférian, R., Steinhoff, T., Stocker, B. D., Sutton, A. J., Takahashi, T., Tilbrook, B., van der Laan-Luijkx, I. T., van der Werf, G. R., van Heuven, S., Vandemark, D., Viovy, N., Wiltshire, A., Zaehle, S., and Zeng, N.: Global Carbon Budget 2015, Earth Syst. Sci. Data, 7, 349-396, doi:10.5194/essd-7-349-2015, 2015.

Lewis, E. and Wallace, D. W. R.: Program Developed for $\mathrm{CO}_{2}$ System Calculations, Carbon Dioxide Information Analysis Center, Oak Ridge National Laboratory, US Department of Energy, Oak Ridge, Tennessee, USA, 1998.

Lueker, T. J., Dickson, A. G., and Keeling, C. D.: Ocean $p \mathrm{CO}_{2}$ calculated from dissolved inorganic carbon, alkalinity, and equations for $\mathrm{K} 1$ and $\mathrm{K} 2$ : validation based on laboratory measurements of $\mathrm{CO}_{2}$ in gas and seawater at equilibrium, Mar. Chem., 70, 105-119, 2000.

McLaughlin, K., Weisberg, S. B., Dickson, A. G., Hofmann, G. E., Newton, J. A., Aseltine-Neilson, D., Barton, A., Cudd, S., Feely, R. A., Jefferds, I. W., Jewett, E. B., King, T., Langdon, C. J., McAfee, S., Pleschner-Steele, D., and Steele, B.: Core principles of the California Current Acidification Network: Linking chemistry, physics, and ecological effects, Oceanography, 28, 160$169,2015$.

McPhaden, M. J.: Playing hide and seek with El Niño, Nature Climate Change, 5, 791-795, 2015.

McPhaden, M. J., Meyers, G., Ando, K., Masumoto, Y., Murty, V. S. N., Ravichandran, M., Syamsudin, F., Vialard, J.. Yu, L., and Yu, W.: RAMA: The Research Moored Array for African-AsianAustralian Monsoon Analysis and Prediction, B. Am. Meteorol. Soc., 90, 459-480, 2009.

Millero, F. J.: The marine inorganic carbon cycle, Chem. Rev., 107, 308-341, 2007.

Mills, K. E., Pershing, A. J., Brown, C. J., Chen, Y., Chiang, F.S., Holland, D. S., Lehuta, S., Nye, J. A., Sun, J. C., Thomas, A. C., and Wahle, R. A.: Fisheries management in a changing climate: Lessons from the 2012 ocean heat wave in the Northwest Atlantic, Oceanography, 26, 191-195, 2013.

Mora, C., Frazier, A. G., Longman, R. J., Dacks, R. S., Walton, M. M., Tong, E. J., Sanchez, J. J., Kaiser, L. R., Stender, Y. O., Anderson, J. M., Ambrosino, C. M., Fernandez-Silva, I., Giuseffi, L. M., and Giambelluca, T. W.: The projected timing of climate departure from recent variability, Nature, 502, 183-187, 2013.

Mucci, A.: The solubility of calcite and aragonite in seawater at various salinities, temperatures, and one atmosphere total pressure, Am. J. Sci., 283, 780-799, 1983.
Nam, S., Kim, H.-J., and Send, U.: Amplification of hypoxic and acidic events by La Niña conditions on the continental shelf off California, Geophys. Res. Lett., 38, L22602, doi:10.1029/2011g1049549, 2011.

Newton, J. A., Feely, R. A., Jewett, E. B., Williamson, P., and Mathis, J.: Global Ocean Acidification Observing Network: Requirements and Governance Plan, Second Edn., available at: http://www.goa-on.org/docs/GOA-ON_2nd_ edition_final.pdf (last access: 6 September 2016), 2015.

Olafsson, J., Olafsdottir, S. R., Benoit-Cattin, A., Danielsen, M., Arnarson, T. S., and Takahashi, T.: Rate of Iceland Sea acidification from time series measurements, Biogeosciences, 6, 26612668, doi:10.5194/bg-6-2661-2009, 2009.

Orr, J. C., Fabry, V. J., Aumont, O., Bopp, L., Doney, S. C., Feely, R. A., Gnanadesikan, A., Gruber, N., Ishida, A., Joos, F., Key, R. M., Lindsay, K., Maier-Reimer, E., Matear, R., Monfray, P., Mouchet, A., Najjar, R. G., Plattner, G.-K., Rodgers, K. B., Sabine, C. L., Sarmiento, J. L., Schlitzer, R., Slater, R. D., Totterdell, I. J., Weirig, M.-F., Yamanaka, Y., and Yool, A.: Anthropogenic ocean acidification over the twenty-first century and its impact on calcifying organisms, Nature, 437, 681-686, 2005.

Orr, J. C., Epitalon, J.-M., and Gattuso, J.-P.: Comparison of ten packages that compute ocean carbonate chemistry, Biogeosciences, 12, 1483-1510, doi:10.5194/bg-12-1483-2015, 2015.

Pershing, A. J., Alexander, M. A., Hernandez, C. M., Kerr, L. A., Le Bris, A., Mills, K. E., Nye, J. A., Record, N. R., Scannell, H. A., Scott, J. D., Sherwood, G. D., and Thomas, A. C.: Slow adaptation in the face of rapid warming leads to the collapse of an iconic fishery, Science, 350, 809-812, 2015.

Pilcher, D. J., Brody, S. R., Johnson, L., and Bronselaer, B.: Assessing the abilities of CMIP5 models to represent the seasonal cycle of surface ocean $p \mathrm{CO}_{2}$, J. Geophys. Res.-Oceans, 120, 46254637, 2015.

Reum, J. C. P., Alin, S. R., Harvey, C. J., Bednaršek, N., Evans, W., Feely, R. A., Hales, B., Lucey, N., Mathis, J. T., McElhany, P., Newton, J., and Sabine, C. L.: Interpretation and design of ocean acidification experiments in upwelling systems in the context of carbonate chemistry co-variation with temperature and oxygen, ICES J. Mar. Sci. (February/March 2016), 73, 582-595, 2015.

Rhein, M., Rintoul, S. R., Aoki, S., Campos, E., Chambers, D., Feely, R. A., Gulev, S., Johnson, G. C., Josey, S. A., Kostianoy, A., Mauritzen, C., Roemmich, D., Talley, L. D., and Wang, F.: Observations: Ocean. In: Climate Change 2013: The Physical Science Basis, Contribution of Working Group I to the Fifth Assessment Report of the Intergovernmental Panel on Climate Change, edited by: Stocker, T. F., Qin, D., Plattner, G.-K., Tignor, M., Allen, S. K., Boschung, J., Nauels, A., Xia, Y., Bex, V., and Midgley, P. M., Cambridge University Press, Cambridge, United Kingdom and New York, NY, USA, 2013.

Rodgers, K. B., Lin, J., and Frölicher, T. L.: Emergence of multiple ocean ecosystem drivers in a large ensemble suite with an Earth system model, Biogeosciences, 12, 3301-3320, doi:10.5194/bg12-3301-2015, 2015.

Salisbury, J., Green, M., Hunt, C., and Campbell, J.: Coastal Acidification by Rivers: A Threat to Shellfish?, Eos, 89, 513-528, 2008.

Salisbury, J., Vandemark, D., Hunt, C., Campbell, J., Jonsson, B., Mahadevan, A., McGillis, W., and Xue, H.: Episodic riverine 
influence on surface DIC in the coastal Gulf of Maine, Estuar. Coast. Shelf S., 82, 108-118, 2009.

Sasse, T. P., McNeil, B. I., Matear, R. J., and Lenton, A.: Quantifying the influence of $\mathrm{CO}_{2}$ seasonality on future aragonite undersaturation onset, Biogeosciences, 12, 6017-6031, doi:10.5194/bg-12-6017-2015, 2015.

Seidel, M. P., DeGrandpre, M. D., and Dickson, A. G.: A sensor for in situ indicator-based measurements of seawater $\mathrm{pH}$, Mar. Chem., 109, 18-28, 2008.

Shadwick, E. H., Trull, T. W., Tilbrook, B., Sutton, A. J., Schulz, E., and Sabine, C. L.: Seasonality of biological and physical controls on surface ocean $\mathrm{CO}_{2}$ from hourly observations at the Southern Ocean Time Series site south of Australia, Global Biogeochem. Cy., 29, 223-238, 2015.

Sutton, A. J., Feely, R. A., Sabine, C. L., McPhaden, M. J., Takahashi, T., Chavez, F. P., Friederich, G. E., and Mathis, J. T.: Natural variability and anthropogenic change in equatorial Pacific surface ocean $p \mathrm{CO}_{2}$ and $\mathrm{pH}$, Global Biogeochem. Cy., 28, 131145, doi:10.1002/2013GB004679, 2014a.

Sutton, A. J., Sabine, C. L., Maenner-Jones, S., Lawrence-Slavas, N., Meinig, C., Feely, R. A., Mathis, J. T., Musielewicz, S., Bott, R., McLain, P. D., Fought, H. J., and Kozyr, A.: A high-frequency atmospheric and seawater $p \mathrm{CO}_{2}$ data set from 14 open-ocean sites using a moored autonomous system, Earth Syst. Sci. Data, 6, 353-366, doi:10.5194/essd-6-353-2014, 2014b.

Takahashi, T., Olafsson, J., Goddard, J. G., Chipman, D. W., and Sutherland, S. C.: Seasonal variation of $\mathrm{CO}_{2}$ and nutrients in the high-latitude surface oceans: A comparative study, Global Biogeochem. Cy., 7, 843-878, 1993.
Takahashi, T., Sutherland, S. C., Chipman, D. W., Goddard, J. G., Ho, C., Newberger, T., Sweeney, C., and Munro, D. R.: Climatological distributions of $\mathrm{pH}, \mathrm{pCO}_{2}$, total $\mathrm{CO}_{2}$, alkalinity, and $\mathrm{CaCO}_{3}$ saturation in the global surface ocean, and temporal changes at selected locations, Mar. Chem., 164, 95-125, 2014.

van Heuven, S., Pierrot, D., Rae, J. W. B., Lewis, E., and Wallace, D. W. R.: MATLAB program developed for $\mathrm{CO}_{2}$ system calculations. ORNL/CDIAC-105b, Carbon Dioxide Information Analysis Center, Oak Ridge National Laboratory, US Department of Energy, Oak Ridge, Tennessee, USA, doi:10.3334/CDIAC/otg.CO2SYS_MATLAB_v1.1, 2011.

Waldbusser, G. G., Hales, B., Langdon, C. J., Haley, B. A., Schrader, P., Brunner, E. L., Gray, M. W., Miller, C. A., and Gimenez, I.: Saturation-state sensitivity of marine bivalve larvae to ocean acidification, Nature Climate Change, 5, 273-280, doi:10.1038/nclimate2479, 2015a.

Waldbusser, G. G., Hales, B., Langdon, C. J., Haley, B. A., Schrader, P., Brunner, E. L., Gray, M. W., Miller, C. A., Gimenez, I., and Hutchinson, G.: Ocean acidification has multiple modes of action on bivalve larvae, PLoS ONE, 10, e0128376, doi:10.1371/journal.pone.0128376, 2015b.

Weiss, R. F.: Carbon dioxide in water and seawater: the solubility of a non-ideal gas, Mar. Chem., 2, 203-215, 1974.

Xue, L., Cai, W.-J., Hu, X., Sabine, C., Jones, S., Sutton, A. J., Jiang, L.-Q., and Reimer, J. J.: Sea surface carbon dioxide at the Georgia time series site (2006-2007): Air-sea flux and controlling processes, Prog. Oceanogr., 140, 14-26, 2016. 